\title{
The Announcement Effect of Open-Market Share Buybacks: The Case for European Firms
}

\author{
Jyoti Gupta $^{1} \&$ Florian Wagner ${ }^{2}$ \\ ${ }^{1}$ ESCP Europe, Paris, France \\ ${ }^{2}$ ESCP Europe London, London, United Kingdom \\ Correspondence: Jyoti Gupta, ESCP Europe, Paris, France. E-mail: gupta@escpeurope.eu
}

Received: April 6, 2018

Accepted: June 27, 2018

Online Published: July 10, 2018

doi:10.5539/ijef.v10n8p117

URL: https://doi.org/10.5539/ijef.v10n8p117

\begin{abstract}
Using a comprehensive sample of 1830 open-market repurchases of 15 European countries encompassing the period from 1998 until 2013, we analyzed the magnitude and determinants of the share price reaction on announcement. Our results indicate that buyback announcements in Europe lead on average to a significantly positive abnormal return of $0.92 \%$ on announcement day, however, decreasing in firm size and announcement frequency. Additionally, our findings show that the market does not particularly greet the distribution of excess cash to shareholders, but rather when companies take advantage of undervalued stock as market-to-book values are inversely related to announcement returns. Looking at the companies' leverage ratios, the motive of capital structure optimization cannot be supported by the empirical findings. Lastly, with respect to managerial market timing ability we could not observe that buybacks are following a period of share price underperformance, concluding that managers are not able to time the implementation of buyback programs.
\end{abstract}

Keywords: share buybacks, open-market repurchases, announcements, undervaluation, signaling, market timing, free cash flow hypothesis, Europe

\section{Introduction}

The discussion on corporate payout policy has been a heavily discussed research field in the area of corporate finance. Essentially, corporations have two vehicles to return profits to shareholders: either via dividends or share buybacks. In the United States, share buybacks have tremendously increased in popularity in the past few decades. According to The Wall Street Journal, companies in the S\&P 500 repurchased a volume of nearly \$476 billion in 2013 and the fact that repurchase volumes now significantly excel dividend distributions, underlines their importance as a method to distribute profits (Russolillo, 2014). In the late 1990s, national regulations in Europa such as, for example, the Corporation Control and Transparency Act in Germany in May 1998 and the French law no 98-546 of July 1998, abolished existing legal restrictions and authorized share buybacks for public firms in most European economies. These national regulations and, additionally, the Market Abuse Directive 2003/6/EC on insider dealing and market manipulation provided a safe harbour for stock repurchases (Christensen, Hail, \& Leuz, 2012). This led to a strong rise in share buyback volumes in Europe at an even faster pace than in the United States (Eije \& Megginson, 2008), highlighting the increasing relevance of share buybacks as an instrument of corporate distributions.

Ever since, literature heavily discussed the motivations why companies engage in share repurchases. According to various surveys of top financial executives, the reasons to repurchase own stocks range from distributing excess cash to shareholders, countering the dilution of granted stock options, boosting earnings per share metrics, optimizing the company's capital structure, to using buybacks as response to hostile takeover attempts (see, among others, Tsetsekos, Kaufman, \& Gitman, 1991; Baker, Powell, \& Veit, 2003). However, one of the most prevalent arguments in surveys and also academic literature (see, among others, Comment \& Jarrell, 1991; Grullon \& Michaely, 2002; Vermaelen, 2005) is the hypothesis that the management uses buybacks to signal confidence in the company's future earnings prospects, suggesting that the stock is undervalued, namely that the true value of the firm is not accurately reflected in the share price (Asquith \& Mullins, 1986). In line with this idea, the majority of academic papers observes positive abnormal returns on announcement and a positive post-announcement stock price drift (see, e.g., Ikenberry, Lakonishok, \& Veramelen, 1995 and 2000; Chan, Ikenberry, \& Lee, 2007; Peyer \& Vermaelen, 2009; Dittmar \& Field, 2015), however, the announcement effect in 
magnitude being generally smaller in Europe than in the U.S. (Manconi, Peyer, \& Vermaelen, 2015), and partially depending on the methodology used (see, e.g., Bradford, 2008).

A key problem of existing academic literature is that most studies focus on the U.S. market or single countries in Europe, varying in the applied methodology. These variations limit the informative value when doing cross-country comparisons. Therefore, the aim of this paper is threefold. In the first step, by using an identical methodology for a sample of 1830 open-market repurchase announcements from 15 different European countries ranging from January 1998 to December 2013, we analyze the direction and magnitude of the share price reaction on and around the announcement date. In a second step, we assess the determinants of this announcement effect in order to test for several motivations behind the initiation of a buyback. The focus of this analysis lies on testing, among other hypotheses, the undervaluation and free cash flow hypothesis, but also the impact of program size and capital structure on announcement returns. Lastly, we analyze the managerial ability to time the initiation of repurchase programs and the impact of announcement frequency on share price returns. Throughout this paper, our goal is also to identify potential differences between the European countries in our sample.

The major difference to academic literature is that the study at hand does not only assess one or a few selected countries, but applies a consistent methodological approach to a broad set of 15 European countries in order to allow a comparison. So far, probably Manconi et al. (2015) are the only (Note 1) authors also applying an integrated approach to open-market repurchases for 32 countries globally, representing the most comprehensive paper comparable to this. Nevertheless, the paper at hand surpasses the study of Manconi et al. (2015) for the European area significantly and provides substantial academic benefits. In fact, the authors are the only ones testing such a broad set of major buyback hypotheses in the context of a comprehensive sample of European open-market repurchase announcements.

Overall, results indicate that share buyback announcements in Europe lead on average to a significantly positive abnormal return of $0.92 \%$ on the announcement day, which is slightly lower than prior studies. In line with earlier papers, this also documents that announcement returns decrease in firm size, market-to-book value and announcement frequency. Findings show that the market does not particularly greet the distribution of excess cash to shareholders, but rather when companies take advantage of their shares being undervalued over a longer period of time. Moreover, results do not indicate that managers have significant market timing skills when implementing buyback programs as announcements do not follow a period of abnormal share price underperformance. Looking at repurchase frequency, one can find that frequent repurchases are associated with lower announcement returns. This might be due to the market's perception that frequent repurchases are a less credible signal for undervaluation and because companies are rather substituting periodic dividend payments than taking advantage of short-term undervalued share prices.

These findings have several implications for companies. The results suggest that companies substituting dividends with share buybacks find it more difficult to signal undervaluation to the market as frequently repurchasing companies experience lower abnormal returns on announcement. Hence, from a short-term perspective considering announcement returns, there seems to be a tradeoff between using buybacks as a flexible, tax-efficient mechanism of corporate distributions, and utilizing them to communicate share price undervaluation to the market place.

The remainder of this paper is organized as follows. The following section discusses the existing literature on the research area of this paper and builds a set of hypotheses to be tested in the following. Section 3 describes the used data sample, its data sources and presents summary statistics on our sample of European open-market repurchases. Section 4 outlines the underlying event study and regression methodology used in this paper. Section 5 presents uni- and multivariate results on the stocks' reaction on announcement and the determinants of this effect. Lastly, section 6 summarizes the major empirical findings and concludes.

\section{Literature Review and Hypotheses}

\subsection{Hypothesis I: Positive Announcement Effect}

Prior papers already intensively examined share price behavior on announcements of open-market repurchases. The large majority of those studies report on average significantly positive abnormal returns on and around the announcement date (Note 2). Based on the depiction and partial input from Hackethal and Zdantchouk (2006), Table 1 summarizes the major empirical findings of selected previous studies, which are relevant for this paper. As displayed below, in the U.S. for example, three-day cumulative abnormal returns centered around the announcement date average between 2\% and 4\% (see, among others, Vermaelen, 1981; Comment \& Jarrell, 1991; Ikenberry et al., 1995; Stephens \& Weisbach, 1998). For Europe literature provides mixed evidence with overall 
lower returns. For the United Kingdom and France for example, literature observes lower abnormal returns of around $1 \%$ to $2 \%$ (see, e.g., Oswald \& Young, 2004; Rau \& Vermaelen, 2002; Ginglinger \& L'Her, 2006; Andriosopoulos \& Lasfer, 2015), while for Germany abnormal returns are slightly higher between $2.5 \%$ and up to $11.6 \%$ (see, e.g., Schremper, 2002; Gerke, Fleischer, \& Langer, 2003; Hackethal \& Zdantchouk, 2006) (Note $3)$.

Table 1. Announcement effect - empirical results of prior studies

\begin{tabular}{|c|c|c|c|c|c|}
\hline \multirow{2}{*}{$\begin{array}{c}\text { Country/ } \\
\text { Region }\end{array}$} & \multirow[b]{2}{*}{ Study } & \multicolumn{2}{|c|}{ Data } & \multicolumn{2}{|c|}{ Empirical Result } \\
\hline & & Time Period & $\mathrm{N}$ & EventWindow & CAR \\
\hline Australia & Lamba and Ramsay (2000) & $1989-1998$ & 103 & {$[-1 ;+1]$} & $3.3 \%$ \\
\hline Australia & Otchere and Ross (2002) & 1991-1999 & 132 & {$[-1 ;+1]$} & $4.3 \%$ \\
\hline Canada & Li and McNally (1999) & 1989-1992 & 183 & {$[-2 ;+2]$} & $3.7 \%$ \\
\hline Canada & Ikenberry et al. (2000) & $1989-1997$ & 1060 & {$[-15 ;+15]$} & $0.9 \%$ \\
\hline France & Ginglinger and L'Her (2006) & 1998-1999 & 363 & {$[-1 ;+1]$} & $0.6 \%$ \\
\hline France & Andriosopoulos and Lasfer (2015) & $1997-2006$ & 263 & {$[-1 ;+1]$} & $0.8 \%$ \\
\hline Germany & Schremper (2000) & $1998-2000$ & 112 & {$[-1 ;+1]$} & $4.1 \%$ \\
\hline Germany & Gerke et al. (2003) & $1998-2002$ & 120 & {$[-1 ;+1]$} & $6.1 \%$ \\
\hline Germany & Seifert and Stehle (2003) & $1998-2003$ & 192 & {$[-1 ;+1]$} & $5.9 \%$ \\
\hline Germany & Hackethal and Zdantchouk (2006) & $1998-2003$ & 224 & {$[-1 ;+1]$} & $11.6 \%$ \\
\hline Germany & Andriosopoulos and Lasfer (2015) & $1997-2006$ & 194 & {$[-1 ;+1]$} & $2.3 \%$ \\
\hline Japan & Zhang (2002) & $1995-1999$ & 39 & {$[-1 ;+2]$} & $6.0 \%$ \\
\hline Korea & Lee, Jung and Thornton (2005) & $1994-2000$ & 268 & {$[-1 ;+1]$} & $1.6 \%$ \\
\hline Switzer-land & Dumont et al. (2004) & $1999-2003$ & 83 & {$[-2 ;+2]$} & $1.8 \%$ \\
\hline U.K. & Oswald and Young (2002) & $1995-2000$ & 1614 & {$[-1 ;+1]$} & $1.4 \%$ \\
\hline U.K. & Rau and Vermaelen (2002) & $1985-1998$ & 126 & {$[-5 ;+5]$} & $1.1 \%$ \\
\hline U.K. & Rees (1996) & $1981-1990$ & 882 & {$[-2 ;+2]$} & $0.3 \%$ \\
\hline U.K. & Andriosopoulos and Lasfer (2015) & $1997-2006$ & 513 & {$[-1 ;+1]$} & $1.7 \%$ \\
\hline U.S. & Vermaelen (1981) & $1970-1978$ & 243 & {$[-1 ;+1]$} & $3.1 \%$ \\
\hline U.S. & Comment and Jarrell (1991) & $1985-1988$ & 1197 & {$[-1 ;+1]$} & $2.3 \%$ \\
\hline U.S. & Ikenberry et al. (1995) & $1980-1990$ & 1239 & {$[-2 ;+2]$} & $3.5 \%$ \\
\hline U.S. & Stephens and Weisbach (1998) & $1981-1990$ & 591 & {$[-1 ;+1]$} & $2.7 \%$ \\
\hline U.S. & McNally (1999) & $1984-1988$ & 702 & {$[-1 ;+1]$} & $2.6 \%$ \\
\hline U.S. & Grullon and Michaely (2002) & $1980-1997$ & 3935 & {$[-1 ;+1]$} & $2.6 \%$ \\
\hline U.S. & Kahle (2002) & $1993-1996$ & 712 & {$[-1 ;+1]$} & $1.6 \%$ \\
\hline U.S. & Grullon and Michaely (2004) & $1980-1997$ & 4443 & {$[-1 ;+1]$} & $2.7 \%$ \\
\hline U.S. & Lie (2005) & $1981-2000$ & 4729 & {$[-1 ;+1]$} & $3.0 \%$ \\
\hline U.S. & Manconi et al. (2015) & $1998-2010$ & 11096 & {$[-1 ;+1]$} & $2.2 \%$ \\
\hline Europe & Andriosopoulos and Lasfer (2015) & $1997-2006$ & 177 & {$[-1 ;+1]$} & $1.6 \%$ \\
\hline Globally, Non-U.S. & Manconi et al. (2015) & $1998-2010$ & 9034 & {$[-1 ;+1]$} & $1.4 \%$ \\
\hline
\end{tabular}

Note. This table reports a non-exhaustive overview of empirical findings for cumulative abnormal returns (CARs) around the announcement date of open-market share repurchases. The table has been partly adopted from the paper of Hackethal and Zdantchouk (2006) and complemented with further major results. Some displayed results refer to the open-market repurchase subsample of the respective paper only. $\mathrm{N}$ is the study's number of observations.

Following Manconi et al. (2015), the country differences in abnormal return are due to differences in corporate governance quality and regulation. In fact, the authors find significantly lower announcement returns in Europe, arguing that in many countries corporate governance quality is low and shareholder approval is required for buyback programs. Overall, the authors find that the differences in the announcement effect are depending on if countries are classified as 'English common law', 'German civil law', 'Scandinavian civil law', or 'French civil law', whereas the last group does not show abnormal returns around the announcement date which are statistically different from zero. This might explain why the lowest abnormal returns are reported for France.

Notably, all mentioned studies share the finding of significantly positive abnormal returns, supporting the signaling. Through the announcement of a buyback, the management reveals new information to the market, signaling better future prospects for the company. These signals about future cash flows and earnings suggest a 
current undervaluation of the stock and are perceived positively by the market. Equally, the positive share price effect could be explained by the free cash flow hypothesis, where agency conflicts can be reduced by returning free cash to shareholders (Kahle, 2002). Reducing the amount of free cash being at the management's disposal may mitigate existing agency cost, which, in turn, is perceived positively by the market (Jensen, 1986). One could argue that a buyback also signals a lack of profitable investment opportunities, which should result in a negative effect. However, Jensen (1986) argues that market participants are already aware of missing future investment opportunities. Also Grullon et al. (2002) argue that the market is aware of missing opportunities to invest profitably, however, less aware of the possible decline of the company's risk profile that comes with a reduction of the amount of cash available at the management's discretion. Based on this discussion we formulate our first hypothesis as follows:

$H_{I}$ : An announcement to repurchase own shares through an open-market transaction is a credible signal to the market (i.e. about better future earnings and profitability prospects), leading on average to a positive abnormal return on the announcement date.

\subsection{Hypothesis II: Free Cash Flow Hypothesis}

As mentioned in the argumentation above, the distribution of excess cash to shareholders can mitigate agency costs, which is welcomed by the market and leads to positive abnormal returns on announcement. In line with this view, Grullon and Michaely (2004) report that a reduction in free cash has a positive effect on a company's share price. Also Bagwell and Shoven (1998) and Evans et al. (2000) report a positive correlation between abnormal returns and the amount of excess cash available at the management's discretion. Thus, we test the free cash flow hypotheses with the following conjecture:

$H_{I I}$ : The amount of cash held by a company is positively associated with the magnitude of the abnormal return on the announcement date.

\subsection{Hypothesis III: Undervaluation Hypothesis}

Undervaluation is a prominent motive for share buybacks. When the true value is not reflected in the share price, managers can take advantage of undervalued stock by repurchasing their own shares. Ikenberry et al. (1995) argue that if undervaluation is a major reason, it should be particularly important for firms with a low market-to-book value. In fact, following the authors, stocks with low market-to-book value ('value stocks') are more likely to be undervalued than stocks with a high market-to-book value ('glamour stocks') (Note 4). Hackethal and Zdantchouk (2006) argue that a low market-to-book ratio tends to increase the perceived potential for undervaluation and, hence, might be associated with a stronger share price reaction on announcement. Additionally, Bagwell and Shoven (1988) also argue in favor of a negative relationship, however, from a different perspective. The authors suggest that stocks with a low market-to-book value have only poor investment opportunities. Thus, the market place welcomes the distribution of cash. Therefore, the third hypothesis is as follows:

$H_{\text {III }}$ : Undervaluation represents a major motive to repurchase stock. Therefore, potentially undervalued stocks (i.e. stocks with a low market-to-book value) reveal higher abnormal returns on the announcement of repurchase programs.

Prior papers document mixed results for this hypothesis. While the results of Ikenberry et al. (1995) show almost equally strong announcement effects for their U.S. subsamples based on different market-to-book values, Andriosopoulos and Lasfer (2015) also find no significant evidence for a negative relationship in Europe. In contrast, Hackethal and Zdantchouk (2006) report for Germany a strong and significant impact of the market-to-book value on the abnormal return on and around the announcement date.

\subsection{Hypothesis IV: Capital Structure Optimization Hypothesis}

A decision to implement a share buyback program is always also a capital structure decision, resulting in an increase of the firm's debt-to-equity ratio without borrowing new debt. This can generally enable a company to lower its weighted average cost of capital (WACC) as long as the cost of debt is lower than the cost of equity. Hence, the firm value can be increased. Also Andriosopoulos and Lasfer (2015) argue that an increase in leverage should therefore be appreciated by investors and lead to positive abnormal returns. In addition, when financed with new debt, a higher leverage can also lead to potential tax shields, increasing the value of the firm. Related to this, Vermaelen (1981) reports higher announcement returns when companies finance their repurchase with debt. Overall, several studies find evidence for the motive to alter a firm's capital structure (see, among others, Hovokimian et al., 2001; Lie, 2002; Jagannathan \& Stephens, 2003; Mitchell \& Dharmawan, 2007). Furthermore, Dittmar (2000) reports that companies engaging in share repurchases reveal lower leverage ratios 
than their industry peers and, additionally, that the difference between a company's target and actual capital structure is a predictor of repurchase activity. Thus, the fourth hypothesis to be tested is:

$H_{I V}$ : The repurchase motive to increase the leverage ratio is greeted by the market. Hence, a higher leverage should be associated with a stronger abnormal return on announcement.

\subsection{Hypothesis V: Program Size Effect}

This hypothesis refers to the size of a repurchase program, expressed by the publicly announced percentage of shares outstanding intended to be repurchased by the company. In fact, the percentage of shares sought is related to the free cash flow hypothesis above. The announcement of the repurchase size (payout size) quantifies the amount of free cash to be distributed. Therefore, the higher the intended amount of shares sought, the stronger the agency cost reduction effect. In addition, the variable can also be seen as a proxy for the credibility of the management's signal. A management that believes its shares are dramatically undervalued would aim at repurchasing the highest amount possible under its current repurchase authorization.

One could argue that the announcement of an open-market repurchase represents merely an option and no actual obligation. However, Stephens and Weisbach (1998) report a strong correlation between the percentage announced and the market's expectation regarding ensuing buybacks. In general, a positive relationship between the percentage of shares sought and the stock's reaction has been investigated and confirmed by many scholars for the U.S. (see, among others, Grullon and Michaely, 2002; Kale, 2002; Zhang, 2005). Therefore, this relationship is tested for Europe based on the following hypothesis:

$H_{V}$ : The relative size of a repurchase program (i.e. the percentage of shares outstanding sought) is positively associated with the share price reaction on the announcement date.

\subsection{Hypothesis VI: Managerial Timing Ability}

Brav, Graham, Harvey and Michaely (2005) document in their survey that the large majority of CFOs in their sample states to repurchase shares in times their firms' shares are undervalued, suggesting that they have market-timing ability when announcing share buybacks. Several papers support this view. Stephens and Weisbach (1998) report negative abnormal returns prior to the fiscal quarter of the announcement, suggesting that managers take advantage of the opportunity to repurchase undervalued shares. Also the findings of Comment and Jarrell (1991) suggest that OMRs are announced following a decrease in the company's share price. More specifically, in the context of OMRs in particular, Brockman and Chung (2001) and Chan et al. (2007) find evidence that managers have significant timing ability within their samples. Looking at monthly repurchase volumes instead of price data, Ikenberry et al. (2000) also report for their Canadian sample evidence for managerial timing ability during the program. According to the author, companies repurchase less shares when abnormal stock returns are high. Contrarily to these findings, other authors such as Cook, Krigman and Leach (1999) and Ridder (2015) find mixed results for their U.S. and Swedish sample without a clear evidence of managers timing the market. Nevertheless, the concept of an informed management being able to time the implementation of repurchase programs following relative underperformance of the stock in question remains intuitive. Consequently, we formulate our sixth hypothesis as follows:

$H_{V I}$ : Assuming asymmetric information, managers have an information advantage compared to outside investors. Hence, supposing that they possess market-timing skills and, as they are free to initiate a buyback at their discretion, it can be contended that managers take advantage of short-dated time periods when the shares underperformed. Thus, one can expect opportunistic behavior and the initiation of buybacks generally following a period of negative abnormal share price performance prior to the announcement.

\subsection{Hypothesis VII: Repurchase Announcement Frequency}

Studying the motives of multiple open-market repurchases, Jagannathan and Stephens (2003) emphasize in their paper that repurchases should not be seen as single, isolated events. The authors argue that the buyback motives of frequently and infrequently repurchasing firms differ substantially, whereas firms implementing programs on a frequent basis rather use buybacks in order to distribute cash and substitute dividends. For infrequently repurchasing firms, however, a buyback is more likely a credible signal of undervaluation. Based on this reasoning of Jagannathan and Stephen (2003), our seventh hypothesis is as follows:

$H_{V I I}$ : Frequently repurchasing firms send a less credible undervaluation signal to the market. Therefore, it can be presumed that frequently repurchasing firms reveal significantly lower abnormal returns on and around announcement than infrequently repurchasing companies.

In line with this hypothesis Jagannathan and Stephens (2003) report a stronger reaction for infrequent 
repurchases in their U.S. sample. Additionally, the authors find that frequently repurchasing firms are larger, have a more stable operating income and higher market-to-book ratios. Also the results of Andriosopoulos and Lasfer (2015) show a stronger announcement effect for firms buying back shares on an infrequent basis in their sample containing European OMRs.

\section{Data Sample}

\subsection{Data Sources and Sample Selection}

In order to examine the aforementioned hypotheses, share buyback information has been obtained from Thomson Reuter's SDC Platinum database, which is one of the world's major databases for financial transactions. Focusing on open-market repurchases, buyback announcements have been employed from the major European economies encompassing the period from January 1998 until December 2013. In addition, the paper acquires the corresponding daily (closing) stock prices and the same data on the countries' respective MSCI indices data from Thomson Reuter's Datastream as total return data. However, as Datastream does not provide prices for all observations in their respective estimation windows, the ones with missing data have been excluded. Further the Worldscope database has been accessed over Datastream to obtain accounting data, namely the companies' last reported total assets prior to the announcement date, as well as the last reported total debt in order to calculate the leverage ratio, which is defined as total debt scaled by total assets. Furthermore, market-to-book value (MTBV) has been acquired two days prior announcement date of the buybacks and the last reported amount of cash. Lastly, after matching the data, the approach of Manconi et al. (2015) has been followed and countries with less than 30 observations during the sample period, as well as going private transactions, namely, those where the percentage of shares sought is 50\% or more have been dropped.

Overall, the final sample used in this paper contains 1830 open-market repurchases from 1336 individual companies (identified by using the Datastream code as unique identifier) announced in the following 15 European countries: Austria, Belgium, Denmark, Finland, France, Germany, Greece, Italy, Netherlands, Norway, Poland, Spain, Sweden, Switzerland and the United Kingdom.

\subsection{Summary Statistics}

First, we glance at the amount of the open-market announcements over time. Figure 1 below provides a distribution of all share buybacks in this sample and plots the MSCI Europe Total Return Index for the corresponding time period.

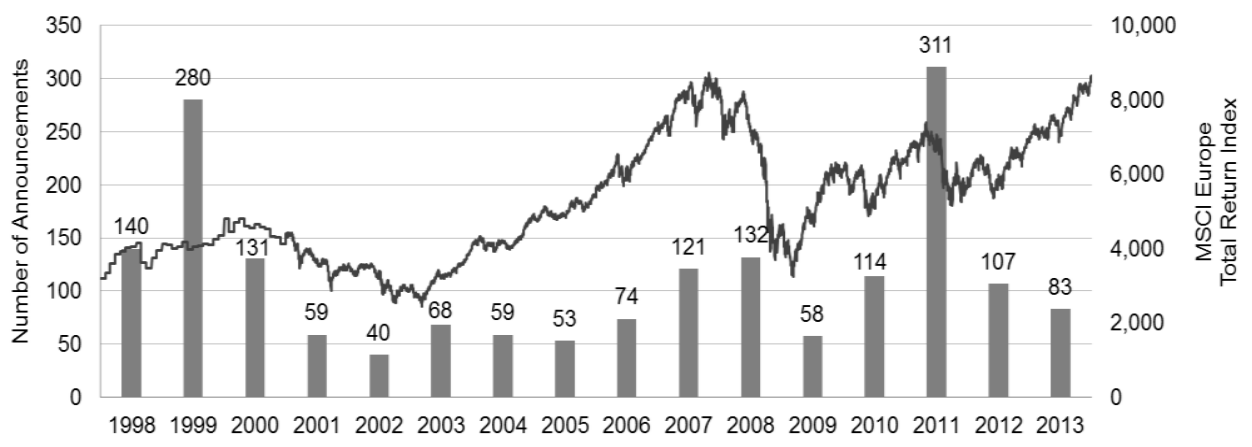

Figure 1. Buyback distribution over time

Additionally considering SDC data from before 1998, it is found that buyback activity significantly accelerated in the 1990s and peaked in 1999, which is likely due to regulatory changes in many European economies and the abolishment of legal restrictions in the late 1990s. Furthermore, comparing the number of buyback announcements to the European benchmark index, it appears that buybacks occur pro-cyclical. In fact, in most years in which the MSCI Europe index revealed a positive (negative) annual return, the number of share repurchases increased (decreased) correspondingly and vice versa. This observation is in line with prior literature suggesting that buybacks are announced in waves (Hackethal and Zdantchouk, 2006) and behave pro-cyclical (Jagannathan, Stephens, \& Weisbach, 2000).

A possible reason for the cyclical behavior could be that companies are hesitant to cut dividends, trying to keep dividend payouts stable or increasing (Lintner, 1956). Thus, repurchases are a flexible way for corporate distribution of excess cash or non-recurring cash flows to shareholders. In line with this argumentation, Jagannathan et al. (2000) report that repurchases are utilized by firms with higher temporary non-operating cash 
flows, increasing disproportionately relative to dividends during economic boom times. Another explanations is provided by Vermaelen (2005) who argues that the pro-cyclical occurrence of buybacks might be because of granted stock options being in-the-money, while the companies try to counteract the dilution by repurchasing own shares.

Figure 2 displays the number of buyback announcements grouped by the announcement months. With a clear peak in May, it is found that $34.81 \%$ of the announcements occur in the months of April and May, and 56.18\% in the four-month period between March and June.

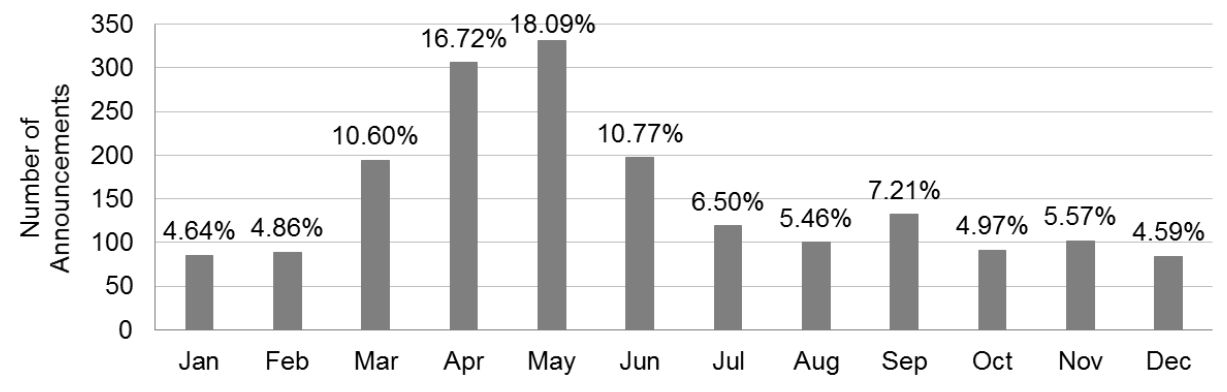

Figure 2. Buyback distribution per month

One possible reason might be that the implementation of repurchase programs could be announced at and around the Annual General Meeting of the shareholders of a company, which are often held in the months around May. However, Hackethal and Zdantchouk (2006) document for Germany the highest amount of announcements in the second half of the year, arguing that companies try to boost their share price at the end of the year. Looking at the distribution of this sample, it does not appear that companies try to improve share price performance toward the end of the companies' reporting year, which falls for the majority of the companies on December.

Furthermore, with respect the companies' announcement frequency; it is found that the average company in this sample announces about 1.37 repurchases between January 1998 and December 2013. Panel A of Table 2 presents a distribution of the number of repurchase announcements. As displayed, the majority of companies in this sample (75.37\%) announces only one open-market repurchase in the observation period, while only ten companies repurchase own equity more than five times during the 16 years.

Table 2. Descriptive statistics - announcement and industry distribution

\begin{tabular}{|c|c|c|c|c|c|c|}
\hline \multicolumn{7}{|c|}{ Panel A: Announcement Frequency } \\
\hline & \multicolumn{6}{|c|}{ Number of Repurchases } \\
\hline & \multicolumn{2}{|r|}{2} & \multicolumn{2}{|c|}{$\begin{array}{cc}\text { Number of Repurchases } \\
3\end{array}$} & 5 & $>5$ \\
\hline Number of Firms & 1,007 & 229 & 69 & 15 & 6 & 10 \\
\hline$\%$ of Sample & $75.37 \%$ & $17.14 \%$ & $5.16 \%$ & $1.12 \%$ & $0.45 \%$ & $0.75 \%$ \\
\hline \multicolumn{7}{|c|}{ Panel B: Sample Distribution Over Industries } \\
\hline \multirow[t]{2}{*}{ Industry } & & \multirow[t]{2}{*}{ SIC Code } & \multicolumn{2}{|c|}{ Announcements } & \multicolumn{2}{|c|}{ Firms } \\
\hline & & & $\mathrm{N}$ & $\%$ of Sample & $\mathrm{N}$ & $\%$ of Sample \\
\hline \multicolumn{2}{|c|}{ Agriculture, Forestry and Fishing } & 0100-0999 & 10 & $0.55 \%$ & 8 & $0.60 \%$ \\
\hline \multicolumn{2}{|l|}{ Mining } & $1000-1499$ & 47 & $2.57 \%$ & 28 & $2.10 \%$ \\
\hline \multicolumn{2}{|l|}{ Construction } & $1500-1799$ & 42 & $2.30 \%$ & 30 & $2.25 \%$ \\
\hline \multicolumn{2}{|l|}{ Manufacturing } & 2000-3999 & 745 & $40.71 \%$ & 523 & $39.15 \%$ \\
\hline \multicolumn{2}{|c|}{ Transportation \& Communications, Electric, Gas } & $4000-4999$ & 178 & $9.73 \%$ & 123 & $9.21 \%$ \\
\hline \multicolumn{7}{|l|}{ \& Sanitary Services } \\
\hline \multicolumn{2}{|l|}{ Wholesale Trade } & $5000-5199$ & 48 & $2.62 \%$ & 37 & $2.77 \%$ \\
\hline \multicolumn{2}{|l|}{ Retail Trade } & 5200-5999 & 65 & $3.55 \%$ & 57 & $4.27 \%$ \\
\hline \multicolumn{2}{|c|}{ Finance, Insurance and Real Estate } & $6000-6799$ & 399 & $21.80 \%$ & 298 & $22.31 \%$ \\
\hline \multicolumn{2}{|l|}{ Service } & $7000-8999$ & 295 & $16.12 \%$ & 231 & $17.29 \%$ \\
\hline \multicolumn{2}{|c|}{ Public Administration } & 9100-9792 & 1 & $0.05 \%$ & 1 & $0.07 \%$ \\
\hline
\end{tabular}

Note. Panel A of this table documents the repurchase announcement frequency, namely the number of companies announcing a certain number of repurchases during the observation period between 1998 and 2013. Panel B reports this sample's 1830 buyback announcements as well as the 1336 firms grouped into ten different industry divisions based on the companies' four-digit Standard Industrial Classification (SIC) codes. 
Panel B of Table 2 presents a distribution of the buyback announcements over ten industry segments classified according to the companies' Standard Industry Classification (SIC) codes. It exhibits that 'Manufacturing' firms represent the largest fraction with $39.15 \%$, followed by financials with $22.31 \%$ and 'Service' with $17.29 \%$. The unequal distribution shows that our following regression analysis requires controlling for industry-fixed effects by adding dummy variables to our regression models.

Lastly, Table 3 summarizes firm and transaction characteristics of the repurchase announcements used in this sample. Looking at the company level, it is found that the firms' mean (median) market-to-book value two days before the announcement is 2.54 (1.62), while it is observed for 422 observations (23.06\% the sample) a market-to-book value of less than one, suggesting that these stocks are currently undervalued as they are traded for less than their book value.

Table 3. Distribution of firm and transaction characteristics

\begin{tabular}{|c|c|c|c|c|c|c|}
\hline & $\mathrm{N}$ & Mean & Median & Std. Dev. & Min & Max \\
\hline Total Assets $^{a}$ & 1301 & 25070 & 662.96 & 125075 & 0.96 & 1988916 \\
\hline Total Debt $^{\mathrm{a}}$ & 1295 & 7025 & 119.15 & 38577 & 0.00 & 566659 \\
\hline Total Cash \& Equivalents ${ }^{a}$ & 1275 & 1003 & 51.67 & 4140 & 0.00 & 94721 \\
\hline Debt Asset Ratio (LEV) ${ }^{\mathrm{b}}$ & 1294 & 21.71 & 18.94 & 18.21 & 0.00 & 89.22 \\
\hline Cash Asset Ratio (CASH) ${ }^{b}$ & 1275 & 15.21 & 9.51 & 17.04 & 0.00 & 99.83 \\
\hline Log of the Total Assets (SIZE) ${ }^{a}$ & 1301 & 8.93 & 8.82 & 1.12 & 5.98 & 12.30 \\
\hline Market-to-Book Value (MTBV) & 1743 & 2.54 & 1.62 & 5.96 & -30.75 & 148.77 \\
\hline Shares Sought $(\text { SOUGHT })^{b}$ & 1489 & 9.33 & 10.00 & 4.58 & 0.10 & 46.90 \\
\hline
\end{tabular}

Note. This table reports the distribution of firm and transaction characteristics within our sample of 1830 buybacks in the time horizon between 1998 and 2013. A detailed overview of the variables, their calculation and data source can be found in the appendix of this paper. ' $\mathrm{N}$ ' stands for the number of observations, namely the number of buyback announcements. a denotes variables in million Euros, while non-Euro currencies have been converted by Datastream. b denotes variables in percentage points.

Furthermore, with respect to the size of the transactions, i.e. the percentage of outstanding shares sought, it is found that companies seek to repurchase on average $9.33 \%$ of the shares outstanding, with a median of $10 \%$. This finding is not surprising, as in many European jurisdictions the maximum number of shares to be repurchased on the open market is legally limited to $10 \%$ of the total number of outstanding shares (Manconi et al., 2015).

\section{Methodology}

\subsection{Event Study}

Mainly guided by the methodology provided by Brown and Warner (1980) and Kothari and Warner (2006), an event study was conducted to isolate the abnormal price impact of buyback announcements. This paper utilizes a standard market model with the stock and market returns simply calculated as the percentage changes in their daily closing prices. The parameters of the model are estimated using daily share price and market returns over a time horizon of 180 trading days during the estimation window $(-200 ;-21)$ relative to the buyback announcement date $(t=0)$, namely between $T_{1}=-200$ and $T_{2}=-21$. Figure 3 illustratively presents the methodological time windows used in this study on a time line.

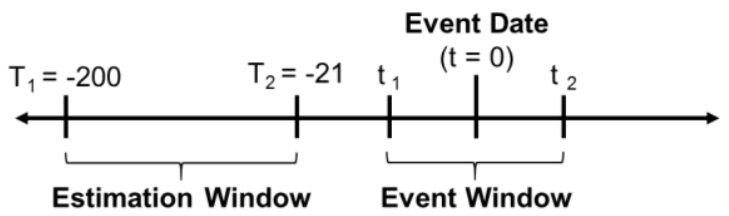

Figure 3. Event study time line

In order to model the normal returns in the market model, this paper consistently utilizes the respective domestic MSCI total return indices from the countries a company is incorporated in as the market (benchmark) portfolio. Consequently, the parameters of the market model are estimated by conducting an OLS regression according to the following equation:

$$
R_{i t}=\hat{\alpha}_{i}+\hat{\beta}_{i} * R_{m t}+\varepsilon_{i t}
$$


$R_{i t}$ is the observed, actual rate of return of a stock $\mathrm{i}$ at day $\mathrm{t}$,

$R_{m t}$ is the respective market return at day $\mathrm{t}$,

$\hat{\alpha} i$ is the intercept of the estimated regression line,

$\hat{\beta} i$ is the slope of the estimated regression line, and

$\varepsilon_{i t}$ is the assumed normally distributed stochastic error term with $E\left(\varepsilon_{i t}\right)=0$.

Based on the estimated regression parameters $\hat{\alpha}$ and $\hat{\beta}$ of the model presented above, the paper computes the securities' normal (expected or predicted) returns $E\left(R_{i t}\right)$ in the event windows based on the market returns using the following equation:

$$
E\left(R_{i t}\right)=\hat{\alpha}_{i}+\hat{\beta}_{i} * R_{m t}
$$

As the next step of the event study this paper computes the abnormal returns, also called excess returns, as the difference between the observed, actual return and the estimated normal return for each company.

$$
A R_{i t}=R_{i t}-E\left(R_{i t}\right)=R_{i t}-\hat{\alpha}_{i}-\hat{\beta}_{i} * R_{m t}
$$

$R_{i t}$ is the observed, actual rate of return of a stock i at day t,

$R_{m t}$ is the respective market return at day $\mathrm{t}$,

$E\left(R_{i t}\right)$ is the expected return of a stock $\mathrm{i}$ at day $\mathrm{t}$, and

$A R_{i t}$ is the abnormal return of a stock $\mathrm{i}$ at day $\mathrm{t}$.

The cumulative effect on a firm level is assessed using the cumulative abnormal return (CAR), simply calculated as the sum of the abnormal returns of a stock i over the time period from $t_{1}$ to $t_{2}$ :

$$
\operatorname{CAR}_{i}\left(t_{1} ; t_{2}\right)=\sum_{t=t_{1}}^{t_{2}} A R_{i t}
$$

$\operatorname{CAR}_{i}\left(t_{1} ; t_{2}\right)$ is the cumulative abnormal return of a stock $\mathrm{i}$ in the time period $\mathrm{t}_{1}$ and $\mathrm{t}_{2}$, and

$A R_{i t}$ is the abnormal return of a stock i at day t.

To measure the cross-sectional effect of a selection of firms, the average abnormal return (AAR) is the average abnormal return of all $\mathrm{n}$ stocks at day $\mathrm{t}$ calculated using the equation:

$$
A A R_{t}=\overline{A R}_{t}=\frac{1}{n} \sum_{i=1}^{n} A R_{i t}
$$

The statistical significance of the average abnormal returns is tested by providing t-statistics computed as:

$$
t_{A A R}=\frac{A A R_{t} * \sqrt{n}}{\sigma_{A A R}}
$$

$t_{A A R}$ is the t-statistic of the average abnormal return,

$A A R_{t}$ is the average abnormal return at day $\mathrm{t}$,

$n \quad$ is the number of stocks to be analyzed, and

$\sigma_{A A R}$ is the cross-sectional standard deviation of abnormal returns at day t, calculated as:

$$
\sigma_{A A R}=\sqrt{\frac{1}{n-1} \sum_{i=1}^{n}\left(A R_{i t}-A A R_{t}\right)^{2}}
$$

Lastly, in order to analyze the aggregated effect over the sample across all stocks and time, the cumulative average abnormal return (CAAR, or mean CAR) is calculated as the sum of the average abnormal returns over the time period $t_{1}$ to $t_{2}$ :

$$
\operatorname{CAAR}\left(t_{1} ; t_{2}\right)=\sum_{t=t_{1}}^{t_{2}} A A R_{t}
$$

$\operatorname{CAAR}\left(t_{1} ; t_{2}\right)$ is the cumulative average abnormal return over the time period from $\mathrm{t}_{1}$ to $\mathrm{t}_{2}$, and

$A A R_{t} \quad$ is the average abnormal return at day $\mathrm{t}$.

Similar to the significance calculation above, the t-statistics for the cumulative average abnormal return are calculated as:

$$
t_{C A A R}=\frac{\operatorname{CAAR}\left(t_{1} ; t_{2}\right) * \sqrt{n}}{\sigma_{C A A R}}
$$

$t_{C A A R}$ is the t-statistic of the cumulative average abnormal return,

$\operatorname{CAAR}\left(t_{1} ; t_{2}\right)$ is the cumulative average abnormal return over the time period from $t_{1}$ to $t_{2}$,

$n \quad$ is the number of stocks in the sample to be analyzed, and

$\sigma_{C A A R}$ is the standard deviation of the cumulative abnormal returns, calculated as: 


$$
\sigma_{C A A R}=\sqrt{\frac{1}{n-1} \sum_{i=1}^{n}\left(C A R_{i}-C A A R\right)^{2}}
$$

The aforementioned t-statistics respectively test the null hypothesis that the (cumulative) abnormal return equals zero. In this analysis we make use of several event windows in addition to the abnormal return on the event date, namely $(-20 ;+20),(-15 ;+15),(-10 ;+10),(-3 ;+3),(-2 ;+2)$ and $(-1 ;+1)$, representing the time horizon in trading days relative of the repurchase announcement date at $\mathrm{t}=0$. Furthermore, the mean CAR for the event windows $(-20 ;-1)$ has been calculated in order to examine eventual pre-announcement underperformance and $(+1 ;+20)$ to assess the short-term stock price drift following the buyback announcement.

\subsection{Multivariate Regression Models}

In this section multivariate OLS regression models have been derived to define the necessary variables in order to test their impact on the announcement returns. Several robust linear regression analyses have been conducted using the abnormal return at announcement and the three-day cumulative abnormal return surrounding the announcement date with the dependent variable, and the following set of independent variables:

- Firm size (SIZE): Following, e.g. Grullon and Michaely (2002) and Dittmar (2000), the log of a firm's assets of the year end prior to the announcement (in million Euros) has been utilized as proxy for firm size. As mentioned before, size can be seen as a proxy for the information asymmetries between the company and the market. The authors argue that larger firms generally publish more information because of stronger disclosure requirements and coverage by analysts. Consequently, the information asymmetry should be reduced so that an announcement leads to a weaker abnormal price effect for large firms. Consequently, the sign of this variable is expected to be negatively correlated.

- Cash (CASH): In line with Grullon and Michaely (2002), this variable is calculated as the company's last reported cash scaled by the last reported book value of its total assets. It is utilized in order to assess in particular the free cash flow hypothesis. According to Jensen (1986) high amounts of held cash can lead to a misalignment between the shareholders' and the managements' interests. In this case investors welcome the distribution of cash, which otherwise might be wasted on negative net present value projects or other value destroying activities. For this reason, the coefficient for the variable CASH is expected to have a positive sign.

- Pre-announcement return (PA_RET): This variable is used to reflect short-term undervaluation prior to the announcement and to assess market timing ability of the company's management to initiate a repurchase. Similar to Isa and Lee (2014), this variable is calculated as the cumulative abnormal return in the time period $(-20 ;-1)$ relative to the announcement date. As argued by Lakonishok and Vermaelan (2000) and Hackethal and Zdantchouk (2006), a low pre-announcement performance is perceived as a credible sign of short-term undervaluation. Consequently, a negative abnormal pre-announcement performance should lead to a stronger, positive abnormal announcement effect. Hackethal and Zdantchouk (2006) also argue that negative past abnormal share price returns can be interpreted as a deliberate indication of timing by the management. The sign of this variable is expected to be negatively correlated.

- Market-to-book value (MTBV): Following Hackethal and Zdantchouk (2006), the variable MTBV is defined as the market-to-book value two days before announcement of a buyback, also referred to as the price-to-book ratio. Generally, a ratio of less than one can be interpreted as a sign for undervaluation, meaning that a company's stock is traded for less than its book value. In fact, Ikenberry et al. (1995) and Hackethal and Zdantchouk (2006) argue that companies with a low market-to-book value have significantly higher abnormal returns when they announce a buyback. Similarly, Bagwell and Shoven (1988) suggest that a company with a low MTBV is perceived to have only poor investment opportunities. For this reason, shareholders welcome the decision to return excess cash, rather than spending it on negative net present value projects. Also Hackethal and Zdantchouk (2006) argue that firms with a low market-to-book value tend to be considered as having a higher potential for undervaluation. Consequently, we expect MTBV to have a negative relationship with abnormal returns.

- Leverage (LEV): Consistent with other studies (see, among others, Dittmar, 2000; Grullon \& Michaely, 2002), this variable is defined as the value of last reported total debt (interest bearing short- and long-term debt) prior to an announcement, divided by the value of the company's last reported total assets. Higher debt ratios might move a company's leverage ratio towards a more optimal capital structure and decrease its WACC, suggesting an increase in firm value. Hence, the rise in leverage ratios might be associated with higher abnormal returns when announcing a buyback. Also Andriosopoulos and Lasfer (2015) argue in favor of a positive relationship. The authors state that firms can take advantage of tax shields by increasing their leverage. Therefore, we expect this variable to be positively correlated. 
- Shares sought (SOUGHT): This variable is the percentage of outstanding shares sought as announced by the company. It reflects the program size and serves as a proxy for the firm's credibility (Note 6). A larger fraction of the outstanding shares to be repurchased signals a stronger conviction of the management. The variable quantifies the amount of free cash to be distributed and, therefore, can be interpreted as a more credible signal for undervaluation. Furthermore, the larger the program the larger the upward price pressure resulting from repurchasing the shares on the market. Thus, in line with prior studies (e.g., Vermaelen, 1981; Grullon \& Michaely, 2002), this variable is expected to be positively correlated with the abnormal return.

- Repurchase announcement frequency (FREQ): The variable FREQ is used to take the announcement frequency of companies into account. It is defined as a dummy variable, which is set to one for a frequent repurchase, and zero otherwise (infrequent repurchase). Similar to Jagannathan and Stephens (2003), a frequent repurchase is defined as the at least second repurchase of a company announced within a period of five years. The authors argue that frequently repurchasing firms rather use buybacks in order to distribute cash and substitute dividends. Contrarily, a buyback of infrequently repurchasing firms is more likely a credible signal of undervaluation. Thus, we expect the variable to be negatively associated with the abnormal return.

Lastly, the paper includes industry dummies (INDUSTRY) and year dummies (YEAR) as control variables in order to account for industry and year fixed effects. Therefore, dummy variables have been created for the announcement years and for the industry divisions based on the companies' SIC codes as displayed before in Panel B of Table 2. Following the same procedure, country dummies (COUNTRY) have been added in order to capture systematic differences in the economic environment of the countries. In summary, the complete empirical model (Note 7) estimated is:

$$
\begin{aligned}
& \text { (Cum.) Abnormal Return }=\gamma_{0}+\gamma_{1} \text { SIZE }+\gamma_{2} \text { CASH }+\gamma_{3} \text { PA_RET }+\gamma_{4} \text { MTBV }+\gamma_{5} \text { LEV } \\
& +\gamma_{6} \text { SOUGHT }+\gamma_{7} \text { FREQ }+\gamma_{8} \text { INDUSTRY }+\gamma_{9} \text { YEAR }+\gamma_{10} \text { COUNTRY }+\varepsilon
\end{aligned}
$$

In order to avoid multicollinearity impacting the regression results when including independent variables in the model, correlation between the aforementioned independent variables has been checked.

Table 4. Correlation matrix of independent regression variables

\begin{tabular}{cccccccc}
\hline & SIZE & CASH & PA_RET & MTBV & LEV & SOUGHT & FREQ \\
\hline SIZE & 1.0000 & & & & & & \\
CASH & $\mathbf{- 0 . 2 8 2 5}$ & 1.0000 & & & & & \\
PA_RET & -0.0841 & 0.0254 & 1.0000 & & & & \\
MTBV & -0.0163 & 0.0702 & -0.0286 & 1.0000 & & & \\
LEV & $\mathbf{0 . 3 0 2 7}$ & $\mathbf{- 0 . 3 4 7 9}$ & 0.0153 & 0.0279 & 1.0000 & & \\
SOUGHT & $\mathbf{- 0 . 2 5 3 7}$ & -0.0349 & 0.1104 & -0.0410 & -0.0811 & 1.0000 & 1.0000 \\
FREQ & 0.1375 & 0.0321 & -0.0574 & -0.0115 & -0.0404 & -0.0626 \\
\hline
\end{tabular}

Note. This table presents the correlation coefficients of the independent regression variables, based on 945 of 1830 observations where all independent variables are available.

Overall, as displayed in Table 4, we observe a weak to medium correlation between the variables SIZE and CASH, SIZE and LEV, SIZE and SOUGHT, and between CASH and LEV. In fact, the matrix reveals that larger companies in this sample tend to hold relatively less cash, have a generally higher leverage ratio and announce repurchases of smaller program size than smaller firms. Overall, these correlations between the independent variables confirm the importance of our approach of testing different settings of the model stated in equation (11) in order to avoid multicollinearity problems.

\section{Empirical Results}

\subsection{Announcement Effect: Univariate Analysis}

This section contains a univariate analysis, exploring the average share price reaction on and around open-market repurchase announcements. Overall, 1058 observations (57.81\% of the sample) had a positive abnormal return on the announcement date, and 772 observations $(42.19 \%)$ had a negative abnormal return. Panel A of Table 5 displays the mean (cumulative) abnormal return for several event windows centered on the repurchase announcement date. The average abnormal return across the entire sample is $0.92 \%$, significantly different from zero at the $1 \%$ level $(\mathrm{t}$-statistic $=8.62)$. The table also reveals that the positive announcement 
effect is consistent for all windows surrounding the announcement, and that a substantial abnormal share price reaction occurs in fact not on, but around the announcement date. Looking at the at the 41-day $(-20 ;+20)$ window, this paper finds a positive abnormal return of $1.71 \%$, also statistically significant at the $1 \%$ level (t-statistic $=$ 3.93).

Table 5. Announcement returns - whole sample

\begin{tabular}{|c|c|c|c|c|c|c|c|c|c|}
\hline & \multicolumn{7}{|c|}{ Panel A } & \multicolumn{2}{|c|}{ Panel B } \\
\hline & \multicolumn{7}{|c|}{ Event Windows Relative to Announcement } & \multicolumn{2}{|c|}{ Pre- and Post- Announcement Windows } \\
\hline & $\mathrm{t}=0$ & $(-1 ;+1)$ & $(-2 ;+2)$ & $(-3 ;+3)$ & $(-10 ;+10)$ & $(-15 ;+15)$ & $(-20 ;+20)$ & $(-20 ;-1)$ & $(+1 ;+20)$ \\
\hline CAAR & $0.92 \%$ & $0.95 \%$ & $1.09 \%$ & $1.03 \%$ & $1.20 \%$ & $1.26 \%$ & $1.71 \%$ & $0.49 \%$ & $0.17 \%$ \\
\hline$t$-stat & $8.62 * * *$ & $5.67 * * *$ & $5.32 * * *$ & $4.56^{* * *}$ & $4.00 * * *$ & $3.47 * * *$ & $3.93 * * *$ & $1.64 *$ & 1.51 \\
\hline
\end{tabular}

Note. Panel A of this table reports the mean CARs over the entire sample for different event windows surrounding the announcement date. Panel B reports the pre- and post-announcement stock return drift, in each case over a 20-day period. *, ** and *** marks statistical significance at the $10 \%, 5 \%$, and $1 \%$ levels, respectively.

This finding is in line with the studies previously presented in Table 1 and shows that open-market repurchase announcements are associated with significantly positive abnormal returns. Compared to Manconi et al. (2015) and Andriosopoulos and Lasfer (2015) for example, the findings appear to be slightly lower with respect to the magnitude of the effect. However, results show that buyback announcements provide new information and are perceived as value-increasing by market participants. Consequently, referring to the first hypothesis, it can be contended that the announcement to repurchase own shares through an open-market transaction represents a credible signal leading on average to a significantly positive abnormal return on the announcement date.

In the next step, the share price reaction has been analyzed over time across the entire sample. Therefore, Figure 4 plots the mean CAR for the 41-day window surrounding the announcement date.

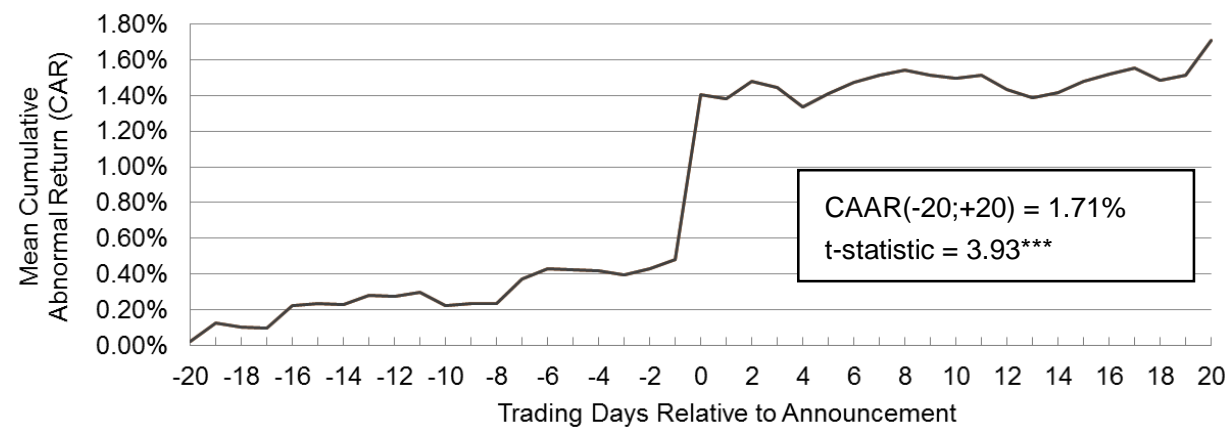

Figure 4. Announcement effect - entire sample

Figure 4 clearly depicts the positive average price reaction on the announcement date. In the 20 days following the announcement the cumulative abnormal return remains mostly stable on the same level, namely in the range between $1.40 \%$ and $1.60 \%$. As shown in Panel B of Table 5, the post-announcement drift in the window $(+1 ;+20)$ amounts to $0.17 \%$ and is not significantly different from zero, suggesting that the market reacts efficiently to the information on the announcement day. In the 20 -day period prior to the announcement date $(-20 ;-1)$, however, a positive abnormal return of $0.49 \%$ has been observed, significant at the $10 \%$ level $(\mathrm{t}$-statistic $=1.64)$. This finding can generally be interpreted as a sign of insider information. As documented by Manconi et al. (2015), a further reason could also be that European regulators require shareholder approval for buyback programs. Consistent with this argumentation and in line with our findings, the authors report positive pre-announcement returns for shareholder approval countries compared to board approval countries. The difference in approval process might also explain generally higher announcement returns in the U.S., where only board approval is required.

With respect to the hypothesis concerning managerial timing ability, positive pre-announcement returns also suggest that managers are in fact not able to time the implementation of share repurchases. If managers would possess the ability to time the announcement of buybacks, one could expect a negative abnormal share price performance prior to the announcement, as managers take advantage when the company's stock is undervalued. 
However, one cannot find evidence to support this hypothesis of significant negative abnormal share price performance prior to the announcement date. Also looking at the daily average abnormal returns around the announcement date confirms this finding and the conclusion also holds true when looking at the share price performance without considering the expected return (Note 8). Hence, the results are not supporting prior results from, among others, Comment and Jarrell (1991), Stephens and Weisbach (1998) or Hackethal and Zdantchouk (2006), who find that the announcement of share repurchases are following a decrease in share prices.

Next, in order to assess if and how the announcement effect varies with firm size and market-to-book value, an approach similar to Zhang (2005) has been followed to construct four subsamples (Q1, Q2, Q3 and Q4) based on four quartiles of the market-to-book value and the firm size, respectively. Consequently, the first (fourth) quartile Q1 (Q4) contains those 25\% of the observations with the lowest (highest) market-to-book value and logarithm of total assets. Table 6 presents the empirical findings.

Table 6. Announcement returns - by subsample

\begin{tabular}{|c|c|c|c|c|c|c|c|c|c|}
\hline \multicolumn{10}{|c|}{ Panel A: By Market-To-Book Value (MTBV) } \\
\hline & & \multicolumn{6}{|c|}{ Event Windows Relative to Announcement } & \multicolumn{2}{|c|}{ Pre- and Post- Announcement Windows } \\
\hline & & $\mathrm{t}=0$ & $(-1 ;+1)$ & $(-2 ;+2)$ & $(-10 ;+10)$ & $(-15 ;+15)$ & $(-20 ;+20)$ & $(-20 ;-1)$ & $(+1 ;+20)$ \\
\hline \multirow{2}{*}{ Q1 } & CAAR & $1.56 \%$ & $2.19 \%$ & $2.30 \%$ & $3.67 \%$ & $4.34 \%$ & $5.31 \%$ & $1.91 \%$ & $0.49 \%$ \\
\hline & $t$-stat & $6.70^{* * *}$ & $6.85^{* * * *}$ & $6.09 * * *$ & $5.33^{* * *}$ & $5.35 * * *$ & $5.40^{* * *}$ & $2.84 * * *$ & $2.29 * * *$ \\
\hline \multirow{2}{*}{ Q2 } & CAAR & $0.89 \%$ & $0.81 \%$ & $1.09 \%$ & $1.32 \%$ & $1.28 \%$ & $2.73 \%$ & $0.53 \%$ & $0.31 \%$ \\
\hline & $t$-stat & $4.85 * * *$ & $3.04 * * *$ & $3.52 * * *$ & $2.54 * *$ & $2.18 * *$ & $3.54 * * *$ & 0.99 & 1.47 \\
\hline \multirow{2}{*}{ Q3 } & CAAR & $0.82 \%$ & $0.47 \%$ & $0.43 \%$ & $0.65 \%$ & $1.31 \%$ & $0.64 \%$ & $0.28 \%$ & $-0.26 \%$ \\
\hline & $t$-stat & $4.87 * * *$ & $1.77 *$ & 1.42 & 1.29 & $2.09 * *$ & 0.90 & 0.56 & -1.22 \\
\hline \multirow{2}{*}{ Q4 } & CAAR & $0.46 \%$ & $0.38 \%$ & $0.69 \%$ & $-0.61 \%$ & $-1.45 \%$ & $-1.44 \%$ & $-0.45 \%$ & $0.03 \%$ \\
\hline & $t$-stat & $1.87 *$ & 0.79 & 1.15 & -0.93 & $-1.84 *$ & -1.56 & -0.72 & 0.11 \\
\hline \multirow{2}{*}{ Q1-Q4 } & CAAR & $1.10 \%$ & $1.29 \%$ & $2.31 \%$ & $1.54 \%$ & $4.34 \%$ & $1.94 \%$ & $2.35 \%$ & $0.46 \%$ \\
\hline & $t$-stat & $3.24 * * *$ & $3.12 * * *$ & $2.28 * *$ & $4.50^{* * *}$ & $5.12 * * *$ & $5.00 * * *$ & $2.57 * *$ & 1.32 \\
\hline \multicolumn{10}{|c|}{ Panel B: By Firm Size (SIZE) } \\
\hline & & \multicolumn{6}{|c|}{ Event Windows Relative to Announcement } & \multicolumn{2}{|c|}{ Pre- and Post- Announcement Windows } \\
\hline & & $\mathrm{t}=0$ & $(-1 ;+1)$ & $(-2 ;+2)$ & $(-10 ;+10)$ & $(-15 ;+15)$ & $(-20 ;+20)$ & $(-20 ;-1)$ & $(+1 ;+20)$ \\
\hline \multirow{2}{*}{ Q1 } & CAAR & $1.24 \%$ & $1.37 \%$ & $1.94 \%$ & $2.17 \%$ & $2.03 \%$ & $3.60 \%$ & $2.34 \%$ & $0.39 \%$ \\
\hline & $t$-stat & $3.86^{* * *}$ & $2.11 * *$ & $2.42 * *$ & $2.57 * *$ & $2.16^{* *}$ & $3.03 * * *$ & $2.79 * * *$ & 1.20 \\
\hline \multirow{2}{*}{ Q2 } & CAAR & $1.03 \%$ & $1.10 \%$ & $1.14 \%$ & $1.61 \%$ & $1.67 \%$ & $1.51 \%$ & $-0.43 \%$ & $0.44 \%$ \\
\hline & $t$-stat & $5.41 * * *$ & $3.31 * * *$ & $2.86^{* * *}$ & $2.26 * *$ & $1.85 *$ & 1.42 & -0.61 & 1.43 \\
\hline \multirow{2}{*}{ Q3 } & CAAR & $0.50 \%$ & $0.19 \%$ & $0.17 \%$ & $-0.91 \%$ & $-0.85 \%$ & $-1.37 \%$ & $-0.81 \%$ & $-0.42 \%$ \\
\hline & $t$-stat & $2.22 * *$ & 0.63 & 0.47 & -1.58 & -1.25 & $-1.79 *$ & -1.59 & -1.43 \\
\hline \multirow{2}{*}{ Q4 } & CAAR & $0.63 \%$ & $0.68 \%$ & $0.62 \%$ & $-0.17 \%$ & $-0.05 \%$ & $0.50 \%$ & $0.10 \%$ & $0.11 \%$ \\
\hline & $t$-stat & $4.20 * * *$ & $3.20 * * *$ & $2.58 * * *$ & -0.39 & -0.09 & 0.73 & 0.19 & 0.67 \\
\hline \multirow[t]{2}{*}{ Q1-Q4 } & CAAR & $0.93 \%$ & $0.69 \%$ & $1.32 \%$ & $2.34 \%$ & $2.08 \%$ & $3.10 \%$ & $2.24 \%$ & $0.28 \%$ \\
\hline & $t$-stat & $1.74 *$ & 1.01 & 1.58 & $2.46^{* *}$ & $1.88^{*}$ & $2.26 * *$ & $2.29 * *$ & 0.76 \\
\hline
\end{tabular}

Note. Panel A and B of this table report the mean (cumulative) abnormal returns for different event windows surrounding the announcement date. The subsamples include only observations where MTBV and SIZE information are available. Panel A is based on 1743 observations, with the quartiles Q1, Q2 and Q3 containing 436 observations, and Q4 containing 435 observations. Panel B is based on 1301 observations, with the quartiles Q1, Q2 and Q3 containing 325, and Q4 containing 326 observations. 'Q1 - Q4' displays the results testing the difference in means between the first and the fourth quartile by applying a two-tailed t-test. *, ** and *** marks statistical significance at the $10 \%, 5 \%$, and $1 \%$ levels, respectively.

First, Panel A provides the (cumulative) abnormal returns for the four subsamples constructed on the basis of market-to-book values. The findings show a clear and consistent pattern. In fact, it is found that the abnormal returns for the first quartile Q1 on and around announcement are the highest among all subsamples and statistically significant at the $1 \%$ level (t-statistics lie in the range between 5.33 and 6.85). The magnitude of the effect monotonically decreases across the quartiles. For Q4 the findings reveal lower and even negative announcement returns for several event windows, however, not all are statistically significant. Additionally, 'Q1 - Q4' tests the difference in means between the two quartiles using a two-tailed t-test. It is also found that for all event windows the abnormal return for subsample Q1 is significantly higher at the $1 \%$ level. Thus, these 
univariate findings support our hypothesis of greater abnormal returns for undervalued firms, namely those with low market-to-book value (mean MTBV of Q1 is 0.48 ). With respect to the pre-and post-announcement windows the authors find only for Q1 a significant reaction, which is statistically higher than for Q4. In fact, the pre-announcement drift is significantly positive, suggesting that the undervaluation has to be interpreted rather over a longer period of time.

Panel B presents the results for the quartiles constructed based on the firm size (SIZE), measured by the logarithm of the companies' total assets in million Euros. In line with our hypothesis, the authors consistently observe the strongest reaction for Q1, namely the subsample containing the 25\% smallest firms in this sample. Exemplarily, for Q1 the average abnormal return on the announcement date is $1.24 \%$ and statistically significant at the $1 \%$ level (t-statistic $=3.86$ ), whereas for $\mathrm{Q} 4$, the effect is only $0.63 \%$, also significant at the $1 \%$ level (t-statistic = 4.20). However, the differences in means for the observed event windows are only partially significant when looking at 'Q1 - Q4'. Also, the results appear not to be completely consistent for Q3 and Q4. Interestingly, the announcement effect is consistently weaker for Q3 than for Q4. In addition, for the first subsample (Q1) the authors observe a strongly positive pre-announcement-return of $2.34 \%$, significant at the $1 \%$ level, whereas the pre-announcement returns for the remaining quartiles are not significantly different from zero. Hence, with regard to firm size, we can only find weak evidence for our hypothesis that smaller firms show significantly higher announcement returns, driven by a more limited availability of price relevant information on smaller firms.

Moreover, with respect to our hypothesis concerning announcement frequency, the approach of Jagannathan and Stephens (2003) has been followed to define a 'frequent' repurchase as the at least second repurchase announced within a period of five years. Based on this classification, the average (cumulative) abnormal returns have been calculated for frequent and infrequent repurchases. Table 7 presents the abnormal returns on and around announcement date for both groups.

When testing the differences in means between frequent and infrequent repurchases, it is clearly observed that infrequently repurchasing companies appear to have a significantly higher abnormal share price reaction around announcement. In fact, the authors find for all windows except the return on announcement a significantly stronger positive effect for infrequent repurchases. While the average three-day CAR is $0.90 \%$ higher for infrequent repurchases (significant at the 5\% level), the average 41 -day CAR is even $4.15 \%$ higher (significant at the $1 \%$ level). In line with our result, Jagannathan and Stephens (2003) suggest that the motivation for frequently repurchasing companies is to substitute dividends, while an infrequent repurchase is rather an action to take advantage of undervalued stock. Thus, the finding supports our initial hypothesis that frequent repurchases are less likely a credible signal for undervaluation and the announcement effect is therefore weaker. It is also observed that the pre- and post-announcement drift is significantly stronger for infrequent repurchases (Note 9).

Table 7. Announcement returns - by announcement frequency

\begin{tabular}{|c|c|c|c|c|c|c|c|c|c|}
\hline & & \multicolumn{6}{|c|}{ Event Windows Relative to Announcement } & \multicolumn{2}{|c|}{ Pre- and Post- Announcement Windows } \\
\hline & & $\mathrm{t}=0$ & $(-1 ;+1)$ & $(-2 ;+2)$ & $(-10 ;+10)$ & $(-15 ;+15)$ & $(-20 ;+20)$ & $(-20 ;-1)$ & $(+1 ;+20)$ \\
\hline \multirow{2}{*}{ Infrequent } & CAAR & $0.98 \%$ & $1.15 \%$ & $1.38 \%$ & $1.69 \%$ & $1.95 \%$ & $2.60 \%$ & $0.78 \%$ & $0.34 \%$ \\
\hline & $t$-stat & $7.71 * * *$ & $5.68 * * *$ & $5.63 * * *$ & $4.80 * * *$ & $4.62 * * *$ & $5.14 * * *$ & $2.24 * *$ & $2.54 * *$ \\
\hline \multirow{2}{*}{ Frequent } & CAAR & $0.69 \%$ & $0.25 \%$ & $0.03 \%$ & $-0.60 \%$ & $-1.24 \%$ & $-1.55 \%$ & $-0.60 \%$ & $-0.44 \%$ \\
\hline & $t$-stat & $4.01 * * *$ & 0.95 & 0.10 & -1.11 & $-1.80 *$ & $-1.95 *$ & -1.12 & $-2.07 * *$ \\
\hline Infrequent & CAAR & $0.30 \%$ & $0.90 \%$ & $1.34 \%$ & $2.28 \%$ & $3.19 \%$ & $4.15 \%$ & $1.37 \%$ & $0.78 \%$ \\
\hline - Frequent & t-stat & 1.15 & $2.20 * *$ & $2.71 * * *$ & $3.14 * * *$ & $3.62 * * *$ & $3.94 * * *$ & $1.90^{*}$ & $2.79 * * *$ \\
\hline
\end{tabular}

Note. This table presents the mean (cumulative) abnormal return for different event windows surrounding the announcement date, split by infrequent and frequent repurchases. A frequent repurchase is defined as the at least second repurchase of a company within a period of five years. Otherwise, if the repurchase is the first repurchase of a company within a period of five years, it is classified as infrequent. 'Infrequent - Frequent' tests the difference in means between the two subsamples by using a two-tailed t-test. *, ** and *** marks statistical significance at the $10 \%, 5 \%$, and $1 \%$ levels, respectively.

As a last step within this univariate analysis, the authors analyze the direction and magnitude of the announcement returns on a country level. Therefore, the (cumulative) abnormal returns have been calculated across several event windows for the entire set of 15 European countries. The findings are presented in Table 8 . 
Table 8. Announcement returns - by country

\begin{tabular}{|c|c|c|c|c|c|c|c|c|c|}
\hline & \multicolumn{7}{|c|}{ Event Windows Relative to Announcement } & \multicolumn{2}{|c|}{$\begin{array}{c}\text { Pre- and Post- } \\
\text { Announcement Windows }\end{array}$} \\
\hline & $\mathrm{t}=0$ & $(-1 ;+1)$ & $(-2 ;+2)$ & $(-3 ;+3)$ & $(-10 ;+10)$ & $(-15 ;+15)$ & $(-20 ;+20)$ & $(-20 ;-1)$ & $(+1 ;+20)$ \\
\hline Austria & $0.92 \%$ & $1.01 \%$ & $1.37 \%$ & $1.86 \%$ & $0.06 \%$ & $-0.53 \%$ & $-0.66 \%$ & $-1.00 \%$ & $0.37 \%$ \\
\hline$t$-statistic & 1.58 & 1.53 & $1.65^{*}$ & $2.06^{* *}$ & 0.06 & -0.43 & -0.43 & -0.79 & 0.91 \\
\hline Belgium & $0.98 \%$ & $1.11 \%$ & $1.44 \%$ & $1.69 \%$ & $-0.48 \%$ & $0.97 \%$ & $3.17 \%$ & $0.49 \%$ & $0.16 \%$ \\
\hline$t$-statistic & $2.09 * *$ & $1.64 *$ & $1.86^{*}$ & $1.70^{*}$ & -0.33 & 0.59 & 1.32 & 0.28 & 0.38 \\
\hline Denmark & $1.23 \%$ & $1.06 \%$ & $1.05 \%$ & $1.42 \%$ & $1.20 \%$ & $1.33 \%$ & $1.54 \%$ & $1.72 \%$ & $0.23 \%$ \\
\hline$t$-statistic & $3.28 * * *$ & $1.90^{*}$ & $1.95^{*}$ & $2.37 * *$ & 1.15 & 1.14 & 1.02 & 1.54 & 0.52 \\
\hline Finland & $0.48 \%$ & $-1.35 \%$ & $-1.49 \%$ & $-1.83 \%$ & $-1.44 \%$ & $-1.77 \%$ & $-1.56 \%$ & $0.14 \%$ & $-1.68 \%$ \\
\hline t-statistic & $1.97 * *$ & $-2.65 * * *$ & $-3.16^{* * *}$ & $-3.05 * * *$ & -1.35 & -1.56 & -0.90 & 0.12 & $-3.70 * * *$ \\
\hline France & $0.06 \%$ & $0.70 \%$ & $0.91 \%$ & $0.97 \%$ & $1.71 \%$ & $2.31 \%$ & $3.42 \%$ & $2.08 \%$ & $0.78 \%$ \\
\hline$t$-statistic & 0.28 & 1.47 & 1.46 & 1.45 & $2.47 * *$ & $2.80 * * *$ & $3.66 * * *$ & $3.00 * * *$ & $2.91 * * *$ \\
\hline Germany & $2.45 \%$ & $2.80 \%$ & $2.92 \%$ & $2.51 \%$ & $2.25 \%$ & $1.72 \%$ & $1.53 \%$ & $-1.31 \%$ & $0.64 \%$ \\
\hline$t$-statistic & $6.35^{* * *}$ & $6.10^{* * *}$ & $5.79 * * *$ & $4.37 * * *$ & $2.76^{* * *}$ & $1.75^{*}$ & 1.32 & $-1.69 *$ & $1.93 *$ \\
\hline Greece & $0.83 \%$ & $0.86 \%$ & $1.46 \%$ & $1.32 \%$ & $2.65 \%$ & $3.65 \%$ & $4.36 \%$ & $1.15 \%$ & $-0.63 \%$ \\
\hline$t$-statistic & $2.11 * *$ & 0.91 & 1.25 & 0.90 & 1.12 & 1.17 & 1.13 & 0.39 & -0.95 \\
\hline Italy & $0.92 \%$ & $1.57 \%$ & $1.68 \%$ & $1.89 \%$ & $3.48 \%$ & $4.88 \%$ & $6.48 \%$ & $2.92 \%$ & $0.03 \%$ \\
\hline$t$-statistic & $2.70^{* * *}$ & $2.97 * * *$ & $2.50 * *$ & $2.60 * * *$ & $2.96 * * *$ & $3.16^{* * *}$ & $3.47 * * *$ & $2.38 * *$ & 0.10 \\
\hline Netherlands & $1.16 \%$ & $2.32 \%$ & $2.55 \%$ & $1.89 \%$ & $-0.55 \%$ & $-1.58 \%$ & $-2.03 \%$ & $-3.19 \%$ & $0.52 \%$ \\
\hline$t$-statistic & $2.49 * *$ & $3.68 * * *$ & $2.74 * * *$ & $1.90^{*}$ & -0.38 & -0.92 & -0.81 & $-1.96 * *$ & 0.90 \\
\hline Norway & $0.28 \%$ & $-1.04 \%$ & $-1.31 \%$ & $-1.62 \%$ & $-1.84 \%$ & $-2.33 \%$ & $-2.48 \%$ & $1.02 \%$ & $-1.10 \%$ \\
\hline$t$-statistic & 0.86 & $-1.78 *$ & $-2.09 * *$ & $-2.19 * *$ & -1.45 & $-1.67 *$ & -1.39 & 1.00 & $-2.11 * *$ \\
\hline Poland & $2.30 \%$ & $5.44 \%$ & $5.89 \%$ & $6.44 \%$ & $8.01 \%$ & $8.16 \%$ & $10.76 \%$ & $2.36 \%$ & $2.71 \%$ \\
\hline$t$-statistic & $2.48^{* *}$ & $3.77 * * *$ & $3.34 * * *$ & $3.31 * * *$ & $2.97 * * *$ & $2.43 * *$ & $2.76 * * *$ & 1.28 & $3.25 * * *$ \\
\hline Spain & $1.07 \%$ & $2.12 \%$ & $1.64 \%$ & $1.35 \%$ & $3.66 \%$ & $3.95 \%$ & $3.08 \%$ & $-0.14 \%$ & $0.37 \%$ \\
\hline t-statistic & $2.14 * *$ & $3.18 * * *$ & $2.43 * *$ & $1.69 *$ & $1.88^{*}$ & $1.67 *$ & 1.08 & -0.07 & 0.83 \\
\hline Sweden & $0.64 \%$ & $-0.84 \%$ & $-0.59 \%$ & $-0.76 \%$ & $-1.47 \%$ & $-1.23 \%$ & $-1.05 \%$ & $-0.49 \%$ & $-0.43 \%$ \\
\hline$t$-statistic & $1.85^{*}$ & -1.41 & -0.88 & -1.02 & -1.48 & -1.07 & -0.73 & -0.52 & -0.75 \\
\hline Switzerland & $0.73 \%$ & $0.74 \%$ & $0.77 \%$ & $0.91 \%$ & $1.09 \%$ & $0.91 \%$ & $0.62 \%$ & $-1.10 \%$ & $0.12 \%$ \\
\hline t-statistic & $3.03 * * *$ & $2.32 * *$ & $2.06 * *$ & $2.21 * *$ & $1.79 *$ & 0.98 & 0.57 & -1.19 & 0.59 \\
\hline United Kingdom & $1.22 \%$ & $1.00 \%$ & $1.37 \%$ & $1.34 \%$ & $2.20 \%$ & $2.11 \%$ & $2.89 \%$ & $0.78 \%$ & $0.04 \%$ \\
\hline t-statistic & $2.74 * * *$ & $2.11 * *$ & $2.25 * *$ & $1.88^{*}$ & $1.98 * *$ & 1.40 & $1.80 *$ & 0.75 & 0.11 \\
\hline
\end{tabular}

Note. This table reports the mean CARs for all countries in the sample on and around the announcement date. Additionally the table displays the pre- and post-announcement stock return drift over a 20-day period. *, ** and $* * *$ marks statistical significance at the $10 \%, 5 \%$, and $1 \%$ levels, respectively.

Overall, there are mixed results on a country level. In fact, for all countries except Austria, France and Norway a positive abnormal return is observed on the announcement date, which is statistically significant at least at the $10 \%$ level. However, the results vary in magnitude. While for Finland the abnormal return is only $0.48 \%$ on announcement $(\mathrm{t}$-statistic $=1.97)$, for Germany the effect is much stronger with $2.45 \%$ (t-statistic $=6.35$ ), statistically significant at the 5\% and $1 \%$ levels, respectively. Additionally, for numerous countries, statistical significance highly depends on the chosen event window. With respect to pre-announcement performance, the author finds that for France and Italy the share price significantly outperforms the benchmark in the 20-day period prior to the announcement by $2.08 \%$ (t-statistic $=3.00$ ) and $2.92 \%(\mathrm{t}$-statistic $=2.38$ ), while in Germany and Netherlands there are significantly negative abnormal returns of $-1.31 \%$ ( $\mathrm{t}$ - statistic $=-1.69$ ) and $-3.19 \%$ $(\mathrm{t}$-statistic $=-1.96)$. Also with respect to the post-announcement period the returns are fairly mixed, highlighting substantial differences across the countries.

Findings with regard to announcement returns are largely in line with the results of Manconi et al. (2015), who are probably the only authors who also provide a comparable in-depth analysis using a consistent methodology for open-market repurchases across multiple countries in Europe. Comparing the cumulative abnormal return for a three-day window centered on the announcement, the authors also observe a significantly positive abnormal reaction for Belgium, Denmark, Germany, Italy, Netherlands, Spain, Switzerland and the United Kingdom. For Finland, France, Greece and Sweden, the authors also find no significant reaction for the cumulative abnormal 
return over three days. Hence, the results differ only with respect to three countries: While Manconi et al. (2015) report a significant positive reaction in Austria and Finland, and no reaction in Norway, there is no significance in Austria, and a negative abnormal return for Finland and Norway. However, the results are also very similar with respect to the magnitude of the effect with for example Germany being the country with the strongest abnormal price reaction of all.

The differences on a country level could be due to various reasons. Manconi et al. (2015) argue that varying announcement effects might be due to differences in the quality of corporate governance and regulation. In fact, when looking at the country's different legal origins, the authors observe that countries with low corporate governance show smaller abnormal returns on announcement. France for example does not only show the lowest governance rating in their study, but also abnormal returns, which are not significantly different from zero, which is similar to this study. Furthermore, as suggested by the authors, the differences might be due to different completion rates. In fact, abnormal returns might be smaller when the market expects buybacks of smaller size than initially announced. However, justifying the announcement returns of all 15 countries with the domestic regulation frameworks and the quality of local corporate governance systems would be beyond the scope of this paper. Nevertheless, this view offers starting points for future studies with a comparative cross-country focus.

In summary, this univariate section documents a significant positive abnormal return when announcing share buybacks on average, as well as for 12 of the 15 countries in this sample. In addition, the authors observe a stronger effect for firms with a low market-to-book value, but no overall consistently stronger effect for smaller firms. Moreover, the results do not provide evidence to support the hypothesis that managers possess market timing skills, as one cannot observe that buybacks are announced following a period of negative abnormal share price returns. But, as the name implies, this univariate analysis does not take any control variables into account. Exemplarily, it might be that companies which are repurchasing their own equity on a frequent basis announce only programs of small size. Hence, the observed lower returns of those firms might be solely driven by program size rather than announcement frequency. As it is not possible from an univariate perspective to isolate the effect of program size holding all other variables constant, the authors further perform a multivariate analysis and control for a variety of factors.

\subsection{Announcement Effect: Multivariate Analysis}

In this section the authors conduct several robust linear regression models, based on the regression model in equation (11) as outlined in the methodology chapter. Within their estimations they use the abnormal return on the announcement date $\operatorname{AR}(0)$ and, additionally - as a robustness check - the three-day cumulative abnormal return CAR $(-1 ;+1)$ as the dependent variable. As independent variables they include SIZE, MTBV, LEV, CASH, PA_RET, SOUGHT and FREQ as defined in the aforementioned section. In all models include two sets of dummy variables in order to control for year and industry fixed effects. While the Models 1 to 4 omit the country dummies, the binary variables have been added in the lastly estimated Model 5 . Due to the correlation between the independent variables, three further variations of the first model have been tested, in order to deal with multicollinearity issues. Table 9 presents our regression results for all models.

Table 9. Multivariate regression results

\begin{tabular}{|c|c|c|c|c|c|c|c|c|c|c|}
\hline & \multicolumn{5}{|c|}{$\mathrm{AR}(0)$} & \multicolumn{5}{|c|}{ CAR $(-1 ;+1)$} \\
\hline & Model 1 & Model 2 & Model 3 & Model 4 & Model 5 & Model 1 & Model 2 & Model 3 & Model 4 & Model 5 \\
\hline \multirow[t]{2}{*}{ SIZE } & -0.004 & -0.003 & & & -0.004 & -0.008 & -0.006 & & & -0.008 \\
\hline & $(2.53)^{* *}$ & $(2.88)^{* * *}$ & & & $(2.22)^{* *}$ & $(2.73)^{* * * *}$ & $(3.13)^{* * * *}$ & & & $(2.63)^{* * *}$ \\
\hline \multirow[t]{2}{*}{ MTBV } & -0.002 & -0.002 & -0.002 & -0.002 & -0.002 & 0.000 & 0.000 & 0.000 & 0.000 & 0.000 \\
\hline & $(2.64)^{* * *}$ & $(1.98)^{* *}$ & $(2.58)^{* *}$ & $(2.41)^{* *}$ & $(2.75)^{* * *}$ & $(0.60)$ & $(0.77)$ & $(0.73)$ & $(0.86)$ & $(0.65)$ \\
\hline \multirow[t]{2}{*}{ LEV } & -0.005 & & & -0.014 & -0.001 & 0.016 & & & 0.003 & 0.022 \\
\hline & $(0.48)$ & & & $(1.67)^{*}$ & $(0.08)$ & $(0.98)$ & & & $(0.23)$ & (1.28) \\
\hline \multirow[t]{2}{*}{ CASH } & 0.013 & & 0.020 & & 0.013 & 0.012 & & 0.016 & & 0.008 \\
\hline & (1.37) & & $(2.20)^{* *}$ & & (1.41) & (1.05) & & (1.51) & & $(0.73)$ \\
\hline \multirow[t]{2}{*}{ PA_RET } & 0.056 & 0.046 & 0.057 & 0.058 & 0.056 & 0.222 & 0.199 & 0.224 & 0.224 & 0.226 \\
\hline & (1.13) & (1.04) & (1.13) & (1.17) & (1.11) & (1.53) & $(1.56)$ & (1.53) & (1.55) & (1.54) \\
\hline \multirow[t]{2}{*}{ SOUGHT } & -0.008 & & 0.013 & 0.008 & -0.018 & 0.000 & & 0.032 & 0.031 & -0.042 \\
\hline & $(0.19)$ & & $(0.31)$ & $(0.20)$ & $(0.42)$ & $(0.01)$ & & $(0.50)$ & $(0.49)$ & $(0.62)$ \\
\hline \multirow[t]{2}{*}{ FREQ } & -0.006 & -0.003 & -0.007 & -0.007 & -0.004 & -0.006 & -0.007 & -0.009 & -0.008 & -0.003 \\
\hline & $(1.97)^{* *}$ & $(1.47)$ & $(2.39) * *$ & $(2.38)^{* *}$ & $(1.54)$ & $(1.37)$ & $(1.83)^{*}$ & $(1.95)^{*}$ & $(1.86)^{*}$ & $(0.63)$ \\
\hline
\end{tabular}




\begin{tabular}{lcccccccccc}
\hline Intercept & -0.006 & 0.015 & -0.049 & -0.023 & -0.010 & 0.050 & -0.067 & -0.019 & -0.006 & 0.056 \\
& $(0.19)$ & $(0.65)$ & $(1.64)^{*}$ & $(0.85)$ & $(0.30)$ & $(1.52)$ & $(2.47)^{* *}$ & $(0.69)$ & $(0.23)$ & $(1.61)$ \\
Year Dummies & Yes & Yes & Yes & Yes & Yes & Yes & Yes & Yes & Yes & Yes \\
Industry Dummies & Yes & Yes & Yes & Yes & Yes & Yes & Yes & Yes & Yes & Yes \\
Country Dummies & No & No & No & No & Yes & No & No & No & No & Yes \\
\hline R2 & 0.15 & 0.10 & 0.15 & 0.14 & 0.18 & 0.16 & 0.13 & 0.15 & 0.15 & 0.19 \\
$\mathrm{~N}$ & 945 & 1,247 & 949 & 962 & 945 & 945 & 1,247 & 949 & 962 & 945 \\
\hline
\end{tabular}

Note. This table displays the regression results, namely the estimated coefficients with robust standard errors based on different regression models of equation (11). In two different regression sets, the model uses the abnormal return on announcement date $\mathrm{AR}(0)$ and the three-day abnormal return CAR $(-1 ;+1)$ as independent variables, respectively. All models include year and industry dummies in order to control for year and industry fixed effects. Model (5) additionally adds the country dummies to the regression. The t-statistics are displayed in parentheses. A description of the variables and their calculation can be found in Table 10 in the appendix of this paper. *, ** and *** marks statistical significance at the $10 \%, 5 \%$, and $1 \%$ levels, respectively.

First, the authors analyze the impact of firm size (SIZE) on the abnormal return. It is found that in all models, the coefficient estimates for the variable SIZE are, as expected, all negative and significantly different from zero, mostly at the $1 \%$ level. While the univariate findings did not fully reveal this size effect, after controlling for various factors, this finding shows that for larger firms the abnormal return on announcement is significantly lower. The finding strongly supports the idea that due to a better information environment for larger companies the announcement effect is weaker than for smaller firms. Larger firms receive generally greater interest from investors, leading to a greater level of information disclosure. Unsurprisingly, the result is consistent with other studies such as, exemplarily Ikenberry et al. (1995) and Lasfer and Andriosopoulos (2015), who also find that abnormal returns decrease in firm size.

Next, the authors look on the impact of undervaluation on announcement returns. With respect to market-to-book value, the univariate results showed on average significantly higher abnormal returns for low MTBV stocks for all analyzed windows. In the regression models, however, there are significant coefficient estimates for the models with the abnormal return on announcement $\operatorname{AR}(0)$ as dependent variable, while the significance disappears for the CAR(-1;+1) models. Therefore, the authors run Model 5, the most informative model with respect to $\mathrm{R}^{2}$, for further dependent variables, namely other CAR windows around the announcement date. Although not displayed here, the authors document significant MTBV estimates for CAR $(-2 ;+2)$ and CAR(-3;+3), significant at the $5 \%$ and $10 \%$ level, respectively. Hence, concluding that the market-to-book value appears to have a significant impact on the announcement effect. These results confirm the initial conjecture. It seems that undervaluation over a longer period is a major motive to repurchase own equity and undervalued firms experience higher abnormal returns on the announcement of repurchase programs. Considering short-term undervaluation however, the results are mixed, similar to the findings of Lasfer and Andriosopoulos (2015). In fact, it is not observed that the estimates for the variable PA_RET, namely the 20-day $(-20 ;-1)$ pre-announcement abnormal return, are inversely related to announcement returns. Contrarily, all models show a positive sign although not of statistical significance. Hence, company motives for buybacks in order 'to make use of undervalued stock' should be interpreted as rather longer-term than short-term undervaluation.

Furthermore, a manager's timing ability can also be assessed by looking at the coefficient estimates for the variable PA_RET. While other authors report larger abnormal announcement returns when stocks relatively underperformed prior to the buyback announcement (see, e.g., Stephens \& Weisbach, 1998; Comment \& Jarrell, 1991; Ikenberry et al., 1995), the authors find no evidence for this relationship. The coefficients are neither negative, nor significantly different from zero for all tested models (with t-statistics in the range between 1.04 and 1.56) (Note 10). Hence, the announcement returns do not seem to be negatively correlated with the abnormal stock return prior to the announcement date. Thus, confirming the univariate results, it cannot be concluded that managers initiate buybacks following a period of negative abnormal share price performance. Managers do not seem to use their information advantage to implement open-market repurchases in order to take advantage of time periods when their firm's stock is undervalued.

Nevertheless, this result might be biased by the fact that regulatory frameworks in Europe require shareholder approval before announcement, limiting the interpretation possibilities of pre-announcement returns as a measure of managerial timing ability. As mentioned before, Manconi et al. (2015) report that pre-announcement returns seem to be higher for countries with shareholder approval than for countries with board approval. Hence, to which extent market timing is even possible when an approval of the shareholders is required is unclear and appears to be an open field in academic research. 
With respect to a company's leverage ratio (LEV), it was supposed that firms repurchase own equity in order to increase their leverage ratio and reach an optimal capital structure. This increase in leverage ratio allows lowering the cost of capital, and increasing the firm value. Additionally, when financed with debt, a buyback can reduce agency cost and generate potential tax savings. However, the authors cannot find evidence for this positive relationship. Based on the regression models above, there was no significant association between a company's leverage ratio and the abnormal return on and around announcement. In fact, only one model shows statistical significance for the respective coefficient estimate, however, at the $10 \%$ only and with negative sign. This finding of no relationship between leverage and announcement returns is in line with the European results of Manconi et al. (2015) and Andriosopoulos and Lasfer (2015) (Note 11). Moreover, the results of Jagannathan and Stephen (2003) show that frequent repurchases tend to have the lowest debt ratios; this suggests that the aim of altering leverage ratios toward an optimal target capital structure seems to be a significant motive for initiating a buyback programs on a frequent basis. However, based on a two tailed t-test, there are no differences in the leverage ratios between frequently and infrequently repurchasing firms (Note 12). Hence, the results do not provide evidence to support the hypothesis that companies utilize buybacks in order to optimize their capital structure.

When testing the free cash flow hypothesis, the focus was on the coefficient estimates for the variable CASH, which is defined as the last reported cash divided by the last reported book value of the company's total assets. As outlined in section 2, the presumption is that the amount of cash held by a firm is positively associated with abnormal return on announcement, since the distribution of excess cash leads to a reduction in agency costs. This is generally welcomed by shareholders, leading to a stronger effect for particularly those firms holding higher amounts of (surplus) cash. As observed in Table 9, it is found for all tested models strongly positive coefficients, however, only one model (Model 3 for AR(0)) reveals statistical significance at the 5\% level ( $t$-statistic $=2.20$ ). As a particularly higher quality can not be attached to this model (Note 13), the authors draw the conclusion that the results provide no evidence for the free cash flow hypothesis. A possible reason might be that our proxy of cash scaled by the last reported total assets does not appropriately reflect the amount of free cash to be distributed.

Looking at the variable SOUGHT, the coefficient estimates are mostly positive, however statistically not different from zero. This finding implies that the announced program size is not associated with the share price reaction on announcement, as reported by for example, Comment and Jarrell (1991), Stephens and Weisbach (1998) or Grullon and Michaely (2002). Hence, the finding does not support our hypothesis of a significant positive relationship, based on the conjecture that the publicly announced percentage of shares outstanding to be repurchased quantifies the amount of free cash to be distributed and serves as a proxy for the credibility of the management's signal. However, the aforementioned authors tested this relationship for a U.S. sample only. In fact, Manconi et al. (2015) also find no evidence for a significant positive relationship between the percentage of shares sought and the abnormal return on announcement in their comprehensive European subsample. The authors argue that in many European countries the maximum percentage allowed to be repurchased is capped at $10 \%$. Consequently, the companies automatically ask for permission to repurchase $10 \%$ of the shares and announce this percentage, mitigating the information content. This may also explain why there is no substantial correlation between the variables CASH and SOUGHT. Firms do not appear to announce the size of the buyback depending on the amount of excess cash they are holding. Another reason for the absence of a significant coefficient estimate in the might be that announcing an open-market repurchase represents no obligation to actually repurchase shares, but only an option to do so.

Lastly, the impact of the announcement frequency (FREQ) on the announcement returns is assessed. As in the univariate analysis, abnormal returns on announcement appear to be lower for a company that frequently repurchases. In fact, the coefficient estimates show that repurchases classified as 'frequent' show on average $0.3 \%$ to $0.9 \%$ lower announcement returns (mostly significantly different from zero). Hence, this supports the hypothesis that frequent repurchases contain less information and send a less credible undervaluation signal to the market, a result which in line with previous studies for Europe (see, e.g., Andriosopoulos and Lasfer, 2015). As Model 5 reveals disappearing significance when including country dummies, it suggests that repurchase frequency varies across countries.

In summary, the uni- and multivariate results reveal several major findings for open-market repurchases in Europe. Firstly, it is observed that open-market repurchase announcements are associated with an average abnormal return of $0.92 \%$ on the announcement day. Furthermore, it is found that this announcement effect significantly decreases in firm size, market-to-book value and repurchase frequency, however, it is independent of the size of the program. Additionally, no evidence for the free cash flow hypothesis could be found. The 
market does not particularly welcome the distribution of excess cash, but rather the fact that a company takes advantage of shares which are undervalued over a longer period. Looking at the capital structure, it appears that announcement returns are independent of leverage, suggesting that buybacks are less likely implemented for capital restructuring reasons (Andriosopoulos and Lasfer, 2015). Moreover, the authors find no indication that managers possess market timing ability when announcing share buybacks as the announcements do not follow a period of negative abnormal performance. On a country level, however, there are substantial differences in announcement returns, which could presumably be explained by varying regulatory frameworks, corporate governance quality and completion rates of buyback programs.

\section{Conclusion}

Since the abolishment of legal restrictions in many European countries in the late 1990s, share repurchases have gained considerable relevance (Eije \& Megginson, 2008). However, so far most academic literature still exclusively focused their studies on the U.S. or single European countries. Additionally, disparate methodologies limit the informative value of comparisons between the existing papers. Therefore, we compile a comprehensive data sample of 1830 open-market repurchases from January 1998 to December 2013 and examine major academic hypotheses by applying a consistent event study methodology across 15 major European countries.

Our empirical analysis reveals several meaningful findings. Looking at the direction and magnitude of the announcement effect, we find a significantly positive average abnormal return of $0.92 \%$ on the announcement day and a cumulative abnormal return of $1.71 \%$ for a 41 -day window surrounding the buyback announcement. Suggesting that buyback announcements are generally welcome by the market place, this result is in line with prior studies, however, slightly lower in its magnitude. Additionally, we find that announcement returns generally decrease in firm size, which might presumably be due to the fact that larger firms receive greater analyst coverage and investor attention.

In line with the undervaluation hypothesis, this paper also documents that undervalued firms, namely those with a low market-to-book value, reveal significantly higher abnormal announcement returns. However, there is no evidence for the free cash flow hypothesis as the market does not react stronger on the announcement of firms holding high amounts of cash. Hence, the mitigation of agency cost by distributing excess cash might not be particularly greeted by investors.

Based on the findings it is contended that companies find it harder to send a credible undervaluation signal to the market if they generally use buybacks as a flexible vehicle to substitute dividends. In fact, observations are that for companies announcing buybacks on a frequent basis (and potentially regularly substituting yearly dividend payments), the announcement effect is significantly lower.

Moreover, the findings are neither able to provide evidence for capital structure optimization as a buyback motive, nor for stronger returns of programs which are larger in size. As the maximum percentage of shares allowed to be repurchased is capped at $10 \%$ in many European jurisdictions and open-market repurchases are no legal obligation to actually repurchase shares, the informative value of the announced program size appears to be limited when explaining announcement returns.

Lastly, with respect to managerial ability to time the initiation of repurchase programs, there is no observation of opportunistic behavior of managers making use of time periods when shares are undervalued. Repurchase announcements do not follow a period of negative pre-announcement performance, which is likely due to the fact that buybacks in Europe require shareholder approval.

The findings have several implications for companies. From a company perspective the results reveal that companies which are substituting dividends with share buybacks find it more difficult to use buybacks as a signal for undervaluation, since frequently repurchasing companies experience lower abnormal returns on announcement. Hence, from a short-term perspective considering the announcement effect, there might a tradeoff between using buybacks as a flexible and tax-efficient mechanism of corporate distributions, and utilizing them as a tool to signal share price undervaluation to the market.

Nevertheless, the analysis presented in this paper has several limitations, mainly as a result of unavailable data. In fact, literature provides further explanatory factors for announcement returns such as ownership concentration, options outstanding, dividend payout, corporate governance quality, tax differentials between dividend income and capital gains tax, as well as the completion rates of previous buyback programs (see, e.g., Grullon \& Michaely, 2002; Vermaelen, 2005; Manconi et al., 2015). These variables were not all included in our models, but were also not considered by any one prior study at the same time. Furthermore, when interpreting this study in the context of other papers, one has to consider that methodological sensitivity appears to play a crucial role 
when computing announcement returns.

However, these limitations open up new fields for academic research. In fact, giving comprehensive reasons for respective short-term share price behavior of the 15 countries would be beyond the scope of this study. Thus, future studies could qualitatively and quantitatively examine to which extent regulatory settings in the countries differ. Based on this, scholars could then try to explain the local market reaction to open-market repurchase announcements.

\section{References}

Andriosopoulos, D., \& Meziane, L. (2015). The market valuation of share repurchases in Europe. Journal of Banking \& Finance, 55, 327-339. https://doi.org/10.1016/j.jbankfin.2014.04.017

Asquith, P., \& David, W. M. (1986). Signalling with Dividends, Stock Repurchases, and Equity Issues. Financial Management, 15, 27-44. https://doi.org/10.2307/3664842

Bagwell, L. S., \& John, B. S. (1988). Share repurchases and acquisitions: An analysis of which firms participate. Corporate takeovers: Causes and consequences, 191-220.

Baker, H. K., Gary, E. P., \& E. Theodore, V. (2003). Why companies use open-market repurchases: A managerial perspective. The Quarterly Review of Economics and Finance, 43, 483-504. https://doi.org/10.1016/S1062-9769(02)00151-5

Bradford, B. M. (2008). Open-market Common Stock Repurchases and Subsequent Market Performance. The Journal of Business and Economics, 14, 45-61.

Brav, A., John, R. G., Campbell, R. H., \& Roni, M. (2005). Payout policy in the 21st century. Journal of Financial Economics, 77, 483-527. https://doi.org/10.1016/j.jfineco.2004.07.004

Brockman, P., \& Dennis, Y. C. (2001). Managerial timing and corporate liquidity: Evidence from actual share $\begin{array}{lllll}\text { repurchases. Journal of Financial } & \text { Economics, } & 61 \text {, }\end{array}$ https://doi.org/10.1016/S0304-405X(01)00068-X

Brown, S. J., \& Jerold, B. W. (1980). Measuring security price performance. Journal of Financial Economics, 8 , 205-258. https://doi.org/10.1016/0304-405X(80)90002-1

Chan, K., David, L. I., \& Inmoo, L. (2007). Do managers time the market? Evidence from open-market share repurchases. Journal of Banking \& Finance, 31, 2673-2694. https://doi.org/10.1016/j.jbankfin.2006.09.017

Christensen, H. B., Luzi, H., \& Christian, L. (2013). Capital-market effects of securities regulation: Prior conditions, implementation, and enforcement. Chicago Booth Research Paper No. 12-04.

Comment, R., \& Gregg, A. J. (1991). The Relative Signalling Power of Dutch-Auction and Fixed-Price Self-Tender Offers and Open-Market Share Repurchases. The Journal of Finance, 46, 1243-1271. https://doi.org/10.1111/j.1540-6261.1991.tb04617.x

Cook, D. O., Laurie, K., \& Leach, J. C. (2004). On the timing and execution of open market repurchases. Review of Financial Studies, 17, 463-498. https://doi.org/10.1093/rfs/hhg028

Dann, L. Y., \& Harry, De A. (1988). Corporate financial policy and corporate control: A study of defensive adjustments in asset and ownership structure. Journal of Financial Economics, 20, 87-127. https://doi.org/10.1016/0304-405X(88)90041-4

Denis, D. J. (1990). Defensive Changes in Corporate Payout Policy: Share Repurchases and Special Dividends. The Journal of Finance, 45, 1433-1456. https://doi.org/10.1111/j.1540-6261.1990.tb03722.x

Dittmar, A. K. (2000). Why Do Firms Repurchase Stock? The Journal of Business, 73, 331-355. https://doi.org/10.1086/209646

Eije, H. V., \& William, L. M. (2008). Dividends and share repurchases in the European Union. Journal of Financial Economics, 89, 347-374. https://doi.org/10.1016/j.jfineco.2007.11.002

Gerke, W., Jörg, F., \& Martin, L. (2003). Kurseffekte durch Aktienrückkäufe - eine empirische Untersuchung für den deutschen Kapitalmarkt. Börsig, C.; Coenenberg, A.: Bewertung von Unternehmen: Strategie - MarktRisiko, 56, 275-304.

Ginglinger, E., \& Jean-Francois, L. (2006). Ownership structure and open market stock repurchases in France. European Journal of Finance, 12, 77-94. https://doi.org/10.1080/13518470500039543

Grullon, G., \& Roni, M. (2002). Dividends, share repurchases, and the substitution hypothesis. The Journal of 
Finance, 57, 1649-1684. https://doi.org/10.1111/1540-6261.00474

Grullon, G., \& Roni, M. (2004). The information content of share repurchase programs. The Journal of Finance, 59, 651-680. https://doi.org/10.1111/j.1540-6261.2004.00645.x

Hackethal, A., \& Alexandre, Z. (2004). Share buy-backs in Germany overreaction to weak signals?, Johann-Wolfgang-Goethe-Universität Frankfurt am Main, Working Paper Series .

Hackethal, A., \& Alexandre, Z. (2006). Signaling Power of Open Market Share Repurchases in Germany. Financial Markets and Portfolio Management, 20, 123-151. https://doi.org/10.1007/s11408-006-0011-9

Hua, Z. (2002). Share repurchases under the commercial law 212-2 in Japan: Market reaction and actual implementation. Pacific-Basin $\quad$ Finance Journal, $10, \quad$ 287-305. https://doi.org/10.1016/S0927-538X(02)00048-3

Hua, Z. (2005). Share price performance following actual share repurchases. Journal of Banking \& Finance, 29, 1887-1901. https://doi.org/10.1016/j.jbankfin.2004.06.038

Ikenberry, D., Josef, L., \& Theo, V. (1995). Market underreaction to open market share repurchases. Journal of Financial Economics, 39, 181-208. https://doi.org/10.1016/0304-405X(95)00826-Z

Ikenberry, D., Josef, L., \& Theo, V. (2000). Stock repurchases in Canada: Performance and strategic trading. The Journal of Finance, 55, 2373-2397. https://doi.org/10.1111/0022-1082.00291

Isa, M., \& Siew-Peng, L. (2014). Market Reactions to Share Repurchase Announcements in Malaysia. Asian Academy of Management Journal of Accounting and Finance, 10, $45-73$.

Jagannathan, M., \& Clifford, S. (2003). Motives for Multiple Open-Market Repurchase Programs. Financial Management, 32, 71-91. https://doi.org/10.2307/3666337

Jagannathan, M., Clifford, P. S., \& Michael, S. W. (2000). Financial flexibility and the choice between dividends and stock repurchases. Journal of Financial Economics, 57, 355-384. https://doi.org/10.1016/S0304-405X(00)00061-1

Jensen, M. C. (1986). Agency cost of free cash flow, corporate finance, and takeovers. American Economic Review, 76.

Kahle, K. M. (2002). When a buyback isn't a buyback: Open market repurchases and employee options. Journal of Financial Economics, 63, 235-261. https://doi.org/10.1016/S0304-405X(01)00095-2

Kai, L., \& William, J. M. (1999). Information signaling or agency conflicts: What explains Canadian open market share repurchases? University of British Columbia, Finance Working Paper.

Kale, J. R., Thomas, H. N., \& Gerald, D. G. (1989). Share repurchase through transferable put rights: Theory and case study. Journal of Financial Economics, 25, 141-160. https://doi.org/10.1016/0304-405X(89)90100-1

Kothari, S. P., \& Warner, J. B. (2006). Econometrics of Event Studies. Espen Eckbo: Handbook of Corporate Finance, 3-32.

Lamba, A. S., \& Ian, M. R. (2000). Share buy-backs: An empirical investigation. Centre for Corporate Law and Securities Regulation, University of Melbourne, Working Paper.

Lie, E. (2000). Excess funds and agency problems: An empirical study of incremental cash disbursements. Review of Financial Studies, 13, 219-248. https://doi.org/10.1093/rfs/13.1.219

Lie, E. (2002). Do Firms Undertake Self - Tender Offers to Optimize Capital Structure? The Journal of Business, 75, 609-639. https://doi.org/10.1086/341637

Lie, E. (2005). Operating performance following open market share repurchase announcements. Journal of Accounting and Economics, 39, 411-436. https://doi.org/10.1016/j.jacceco.2005.04.001

Lintner, J. (1956). Distribution of incomes of corporations among dividends, retained earnings, and taxes. The American Economic Review, 46, 97-113.

Manconi, A., Urs, P., \& Theo, V. (2015). Buybacks Around The World. INSEAD Working Paper 2013/101/FIN.

Mitchell, J. D., \& Grace, V. D. (2007). Incentives for on-market buy-backs: Evidence from a transparent buy-back regime. Journal of Corporate Finance, 13, 146-169. https://doi.org/10.1016/j.jcorpfin.2006.12.002

Oswald, D., \& Steven, Y. (2004). What role taxes and regulation? A second look at open market share buyback activity in the UK. Journal of Business Finance \& Accounting, 31, 257-292. 
https://doi.org/10.1111/j.0306-686X.2004.0007.x

Otchere, I., \& Matthew, R. (2002). Do share buy back announcements convey firm-specific or industry-wide information?: A test of the undervaluation hypothesis. International Review of Financial Analysis, 11, 511-531. https://doi.org/10.1016/S1057-5219(02)00068-6

Peyer, U., \& Theo, V. (2009). The nature and persistence of buyback anomalies. Review of Financial Studies, 22, 1693-1745. https://doi.org/10.1093/rfs/hhn024

Rau, P. R., \& Theo, V. (2002). Regulation, Taxes, and Share Repurchases in the United Kingdom. The Journal of Business, 75, 245-282. https://doi.org/10.1086/338703

Rees, W. (1996). The impact of open market equity repurchases on UK equity prices. The European Journal of Finance, 2, 353-370. https://doi.org/10.1080/13518479600000014

Ridder, A. (2015). Additional evidence on the frequency of share repurchases and managerial timing. The Quarterly Review of Economics and Finance, 56, 154-164. https://doi.org/10.1016/j.qref.2014.09.011

Russolillo, S. (2014). The Great Buyback Binge of 2013 Will Continue: S\&P. The Wall Street Journal (Online), March 26.

Schremper, R. (2002). Aktienrückkauf und Kapitalmarkt: Eine theoretische und empirische Analyse deutscher Aktienrückkaufprogramme.

Stephens, C. P., \& Michael, S. W. (1998). Actual share reacquisitions in open-market repurchase programs. The Journal of Finance, 53, 313-333. https://doi.org/10.1111/0022-1082.115194

Tsetsekos, G. P., Daniel, J. K. Jr., \& Lawrence, J. G. (1991). A survey of stock repurchase motivations and practices of major US corporations. Journal of Applied Business Research (JABR), 7, 15-21. https://doi.org/10.19030/jabr.v7i3.6221

Vermaelen, T. (1981). Common stock repurchases and market signalling: An empirical study. Journal of Financial Economics, 9, 139-183. https://doi.org/10.1016/0304-405X(81)90011-8

Vermaelen, T. (2005). Share Repurchases. Foundations and Trends in Finance, 1, 171-268. https://doi.org/10.1561/0500000007

Yong-Gyo, L., Sung-Chang, J., \& John, H. T. Jr. (2005). Long-term stock performance after open-market repurchases in Korea. Global Finance Journal, 16, 191-209. https://doi.org/10.1016/j.gfj.2005.05.010

\section{Notes}

Note 1. Furthermore, the paper of Andriosopoulos and Lasfer (2015) is similar with regard to the used approach to test several hypotheses, however, focuses on France, Germany and the United Kingdom only.

Note 2. For repurchases announced in the context of takeover defenses Denis (1990) and Dann and DeAngelo (1988) found negative abnormal returns, indicating a violation of shareholder interests in this situation.

Note 3. Previous findings of other buyback methods reveal different results with respect to the magnitude of the effect. For example, Vermaelen (1981) and Comment and Jarrell (1991) report significantly higher excess returns for fixed-price tender offers and Dutch auctions in excess of $10 \%$.

Note 4. Instead of market-to-book value, other authors use negative pre-announcement abnormal return as a sign for undervaluation (see, among others, Comment and Jarrell, 1991; Weisbach and Stephens, 1998). But, this variable only captures potential short-term undervaluation. Hence, although focusing on market-to-book value as a proxy of undervaluation in our regression, we additionally control for abnormal pre-announcement returns.

Note 5. Single companies have been identified by using the Datastream code provided by Thomson Reuter's SDC Platinum database. Hence, a drawback of this identification is that an eventual change in a company's Datastream code during the observation period would lead to an identification of two separate companies. From a methodological standpoint, this might be the reason why we observe a relatively low number of companies with more than five repurchases in the observation period.

Note 6. Other authors such as Comment and Jarrell (1991) utilize the percentage of shares held by the management as a proxy for the credibility of the signal. This approach takes into account the financial exposure of managerial ownership. Hence, when insiders put their wealth at risk, the signal can be interpreted as more credible. However, due to the lack of available data, this variable is not included as an independent variable. 
Note 7. $\varepsilon$ is the assumed normally distributed error term with zero mean and constant variance. The dummy variables YEAR, INDUSTRY and COUNTRY are not displayed separately in this equation.

Note 8. Opposing our initial conjecture, a positive pre-announcement return of $0.73 \%$ is found, significantly different from zero at the $5 \%$ level $(\mathrm{t}$-statistic $=2.44)$.

Note 9. The significant difference between frequent and infrequent buybacks is illustratively depicted in Figure 5 in the appendix of the paper.

Note 10. Although not separately displayed here, this result does not change when utilizing the actual stock price return, instead of the abnormal return.

Note 11. However, a major drawback of using the leverage ratio in order to test for the capital structure hypothesis is, that it is not clear if the company is moving towards a more optimal capital structure, namely if the pre-announcement debt-to-equity ratio is below the target ratio (Lie, 2002).

Note 12. The t-test reveals a difference in means of the debt-asset ratio between the two groups of $1.41 \%$ (t-statistic $=1.22)$, with a mean ratio of $22.08 \%(20.67 \%)$ for infrequently (frequently) repurchasing companies.

Note 13. When looking at Akaike's information criterion (AIC) and the Bayesian information criterion (BIC), it can be observed that Model 3 appears to have only slightly lower and therefore better values. However, it cannot be concluded that Model 3 is of substantially higher statistical quality.

\section{Appendix A}

Table 10. Company and Repurchase Data

\begin{tabular}{|c|c|c|}
\hline & Source & Description \\
\hline Total Assets & $\begin{array}{c}\text { Datastream } \\
\text { (Worldscope) }\end{array}$ & $\begin{array}{l}\text { For all industries, total assets represents the sum of total current assets, long term receivables, } \\
\text { investment in unconsolidated subsidiaries, other investments, net property plant and equipment } \\
\text { and other assets. For banks, it represents the sum of cash \& due from banks, total investments, net } \\
\text { loans, customer liability on acceptances (if included in total assets), investment in unconsolidated } \\
\text { subsidiaries, real estate assets, net property, plant and equipment and other assets. For an } \\
\text { insurance company, it represents the sum of cash, total investments, premium balance } \\
\text { receivables, investments in unconsolidated subsidiaries, net property, plant and equipment and } \\
\text { other assets. } \\
\text { For all other financial companies, it represents the sum of cash \& equivalents, receivables, } \\
\text { securities inventory, custody securities, total investments, net loans, net property, plant and } \\
\text { equipment, investments in unconsolidated subsidiaries and other assets. In this analysis total } \\
\text { assets were obtained as the last reported total assets prior to a repurchase announcement. } \\
\text { Datastream/Worldscope item: WC02999 }\end{array}$ \\
\hline Total Debt & $\begin{array}{c}\text { Datastream } \\
\text { (Worldscope) }\end{array}$ & $\begin{array}{l}\text { Total Debt includes all interest bearing and capitalized lease obligations. It is the sum of long and } \\
\text { short term debt. Datastream/Worldscope item: WC } 03255\end{array}$ \\
\hline $\begin{array}{l}\text { Cash and } \\
\text { Equivalents }\end{array}$ & $\begin{array}{c}\text { Datastream } \\
\text { (Worldscope) }\end{array}$ & $\begin{array}{l}\text { Includes Cash \& Due from Banks for Banks, Cash for Insurance companies and Cash \& Short } \\
\text { Term Investments for all other industries. } \\
\text { Datastream/Worldscope item: WC02005 }\end{array}$ \\
\hline $\begin{array}{l}\text { Market-to-book } \\
\text { Ratio }\end{array}$ & $\begin{array}{c}\text { Datastream } \\
\text { (Worldscope) }\end{array}$ & $\begin{array}{l}\text { The market-to-book ratio is defined as the market value of the ordinary (common) equity divided } \\
\text { by the balance sheet value of the ordinary (common) equity in the company. } \\
\text { Datastream/Worldscope item: MTBV }\end{array}$ \\
\hline $\begin{array}{l}\text { Share Prices } \\
\text { and Index Data }\end{array}$ & Datastream & Share prices and MSCI Index data were obtained daily and the returns were calculated manually. \\
\hline Leverage Ratio & Self-calculated & Defined as the Total Debt divided by the last reported total assets prior to the announcement. \\
\hline $\begin{array}{l}\text { Cash-Asset- } \\
\text { Ratio }\end{array}$ & Self-calculated & $\begin{array}{l}\text { Defined as Cash and Equivalents divided by the last reported total asset prior to the } \\
\text { announcement. }\end{array}$ \\
\hline $\begin{array}{l}\text { Percentage of } \\
\text { Shares Sought }\end{array}$ & SDC Platinum & $\begin{array}{l}\text { Represents the number of shares sought by a respective company as reported on the } \\
\text { announcement date. }\end{array}$ \\
\hline
\end{tabular}

Note. This table describes the used data and the sources from which it has been obtained. The data description has been partly adopted from Thomson Reuters' Datastream manual. 


\section{Appendix B}

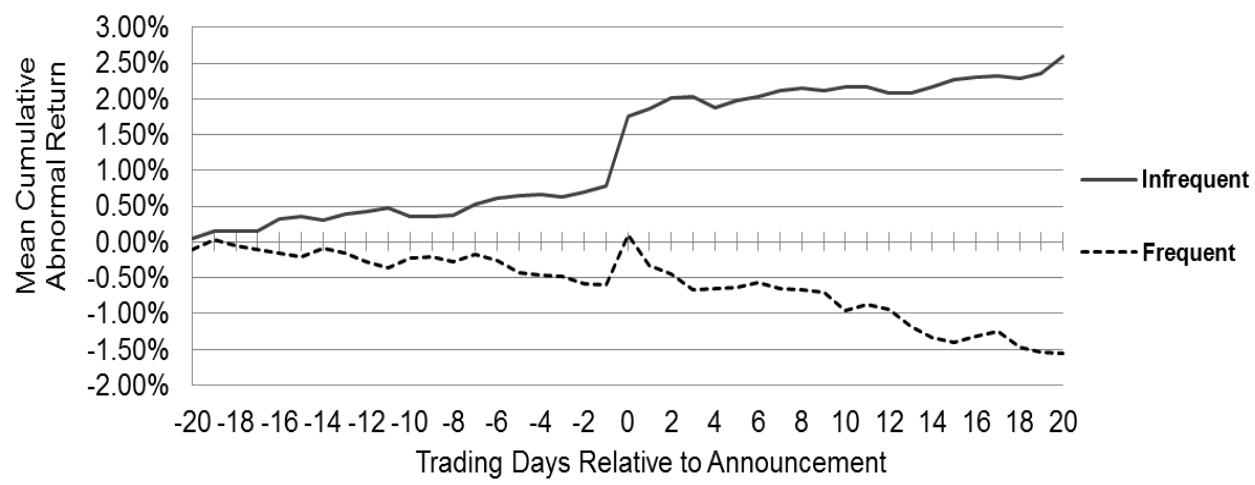

Figure 5. Announcement effect - by announcement frequency

\section{Copyrights}

Copyright for this article is retained by the author(s), with first publication rights granted to the journal.

This is an open-access article distributed under the terms and conditions of the Creative Commons Attribution license (http://creativecommons.org/licenses/by/4.0/). 